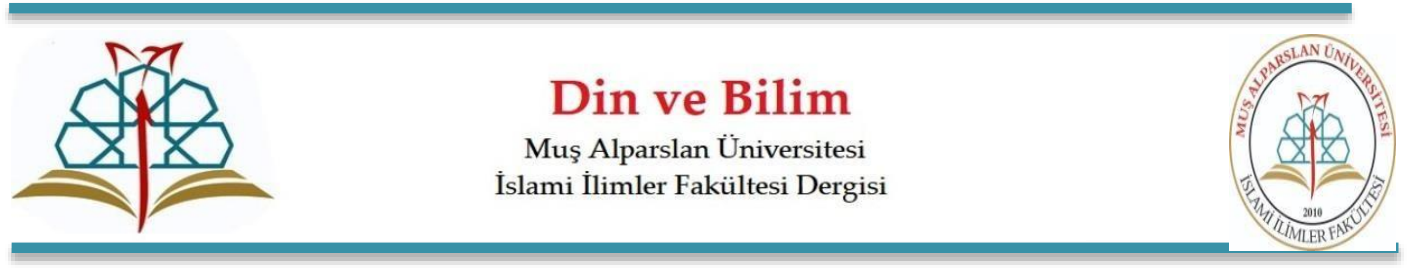

Din ve Bilim - Muş Alparslan Üniversitesi İslami İlimler Fakültesi Dergisi Region and Science - Journal of Muş Alparslan University Faculty of Islamic Sciences e-ISSN: 2667-7717 Aralık/December 2020, 3(2): 49-67

\title{
İhlâs Kavramının Tahlili (Sözlük Bilim ve Kur'ân Âyetleri Özelinde)
}

Analysis of the Concept of Ihlās (in Terms of Lexicography and Qur'ān)

\section{Sümeyye SEVINCÇ}

Arş. Gör. Dr., Kütahya Dumlupınar Üniversitesi, İslami İlimler Fakültesi, Tefsir Anabilim Dalı. PhD. Research Assistant, Kütahya Dumlupınar University, Faculty of Islamic Sciences, Department of Tafsir Kütahya/Turkey sumeyye.sevinc@dpu.edu.tr ORCID: 0000-0002-3083-6453

\section{Makale Bilgisi I Article Information}

Makale Türü / Article Type: Araştırma Makalesi / Research Article

Geliş Tarihi / Date Received: 09 Kasım / November 2020

Kabul Tarihi / Date Accepted: 28 Kasım / November 2020

Yayın Tarihi / Date Published: 31 Aralık / December 2020

Yayın Sezonu / Pub Date Season: Aralık / December

DOI: $10.47145 /$ dinbil.823387

Bu çalışma Sümeyye Sevinç'in Kur'ân'da İhlâs Kavramı isimli lisans bitirme tezinden (Uludağ Üniversitesi İlahiyat Fakültesi, Lisans Tezi, 2010) istifade edilerek hazırlanmıştır. Çalışmama destek veren muhterem hocam Dr. Öğr. Üyesi Mustafa Bilgin'e şükranlarımı sunarım.

Atıf / Citation: Sevinç, Sümeyye. "İhlâs Kavramının Tahlili (Sözlük Bilim ve Kur'ân Âyetleri Özelinde) / Analysis of the Concept of Ihlās (in Terms of Lexicography and Qur'ān)". Din ve Bilim -

Muş Alparslan Üniversitesi İslami İlimler Fakültesi Dergisi 3 / 2 (Aralık 2020): 49-67. doi: 10.47145/dinbil.823387

İntihal: Bu makale, iThenticate yazılımınca taranmıştır. İntihal tespit edilmemiştir. Plagiarism: This article has been scanned by iThenticate. No plagiarism detected. web: https://dergipark.org.tr/tr/pub/dinbil I mailto: dinbil@alparslan.edu.tr

Copyright $@$ Published by Muş Alparslan Üniversitesi, İslami İlimler Fakültesi / Muş Alparslan University, Faculty of Islamic Sciences, Muş, 49250 Turkey. Bütün hakları saklıdır. / All right reserved. 


\title{
Öz
}

Kur'ân muhtevası hususundaki çalışmalar, tefsirin temel araştırma alanları arasında yer almaktadır. Kur'ân muhtevası bağlamında yapılan kavram tahlilleri ise herhangi bir kavramın gerek sözlükler gerekse Kur'ân âyetleri açısından ifâde ettiği manayı bütünlük içerisinde sunabilmektedir. Bu araştırmada söz konusu çalışmalara katkı sağlamak üzere Kur'ân'da lafzî olarak bulunmasa da İslam geleneğinde 1stılahî manasıyla teamül eden "ihlâs" kavramının köken itibariyle ifâde ettiği genel anlamı ve Kur'ân âyetlerinde irtibatlı olduğu kavramlar üzerinde durulmaktadır. Böylelikle zikri geçen kavramın terim haline gelme aşamasında, anlam alanın ortaya koyulması amaçlanmaktadır. Bu bağlamda araştırma esnasında öncelikle söz konusu kavram, sözlükler ve Kur'ân âyetlerinde zikri geçen anlamlar açısından kategorize edilerek değerlendirilmektedir. Bu aşamada kavramın kullanım alanları detaylı olarak tasnif edilmektedir. Ardından kavramın mahiyeti özne ve nesne açısından olmak üzere iki aşamada değerlendirilmektedir. Nihâyetinde kavramın öznesine dair Allah ve insan; nesnesine göre ise iman ve amel boyutunun ortaya çıktığı görülmektedir. Dolayısıyla ihlâsın anlam alanı bu kavramlar ve bunların ilişki ağları çerçevesinde belirlenmektedir.

Anahtar Kelimeler: Tefsir, Sözlük Bilim, Kur'ân, Âyet, İhlâs.

\begin{abstract}
Studies on the content of the Qur'ān are among the basic research areas of tafsir. The conceptual analysis made in the context of the content of the Qur'ān can present the meaning expressed by any concept in terms of both the dictionaries and the verses of the Qur'ān in integrity. In this study, although it is not included in the Qur'ān literally, the general meaning of the concept of "ihlās", which is used in the Islamic tradition in its terminology, as its origin and the concepts related to the verses of the Qur'ān are emphasized in order to contribute to the aforementioned research. In this way, it is aimed to reveal the mentioned concept at the stage of becoming a term. In this context, during the research, the concept in question is categorized and analyzed in terms of the meanings mentioned in the dictionaries and verses of the Qur'ān. The concept is classified and evaluated in two stages as subject and object within the scope of its nature. Ultimately, regarding the subject of the concept, God and human; according to the object, it is seen that the dimension of belief and deeds appears. Thus the scope of the ihlās is determined within the framework of these concepts and their conceptual networks.
\end{abstract}

Keywords: Tafsir, Lexicography, Qur'ān, Verse, Ihlās.

\section{Giriş}

Kur'ân muhtevası çalışmaları kapsamında Kur'ân'da geçen kavramların tahliline yönelik araştırmalar dikkat çekmektedir. Esasında söz konusu çalışmalarda bir taraftan çağdaş dönem yöntemlerinden biri olan semantik analizler yapılmakta, bir taraftan da kavramın terim manasına geçişi ele alınmaktadır. Ancak mezkûr çalışmalara konu edilen kavramlar, ıstılahî mananın öne çıktığ alanlardaki malumat üzerinden değerlendirilmektedir. Bu durumda araştırmalar kavramla ilgili dilbilim ve âyetler üzerindeki tahlillerden ziyade, kavramının ilgili olduğu alanın verilerinden mürekkep bir hal almaktadır. Söz gelimi kavram fıkıhla irtibatlı bir terim manasına geliyorsa fıkhın; kelamla alakalı ise kelamın, kavram tahlillerine hatırı sayılır derecede tesiri söz konusu olmaktadır. $\mathrm{Bu}$ nedenle kimi zaman kavram tahlillerine dair çalışmalar, Arap dilinin ve âyetlerin ihtiva ettiği manaların ötesinde yeni anlamlara yoğunlaşmak suretiyle değerlendirilmiş olmaktadır. Elbette bu bütün kavram tahlillerinde görülen bir sorun değildir. Ne var ki bazı kavramlar üzerinde yapılan çalışmaların belirli alanlara göre sınırlı kalması, söz konusu kavramları yeniden Arap dili ve âyetler özelinde değerlendirmeyi gerekli kılmaktadır.

Araştırmamıza konu olan "ihlâs" kavramı da tasavvufa dair olması hasebiyle hakkında yapılan çalışmalarda genellikle tasavvufî bir bakış açısı ile ele alınmıştır. Esasında kavramla ilgili eserleri genelde Kelime-i tevhîd ve İhlâs Sûresi çerçevesinde; özelde ise kavramın ya Kur'ân'daki yeri ya da semantik tahliline dair çalışmalar açısından iki kısımda ele almak mümkündür. Nitekim kelime-i 
tevhîd ile ilgili olarak ihlâsı konu edinen eserler arasında İbn Receb'in (öl. 795/1393) Kelimetü'l-İhlâs ve Tahkîku Ma`nâhâ adlı telifi örnek verilebilir. ${ }^{1}$ Eserde İbn Receb ihlâsı Kelime-i tevhîd hususundaki samimiyet üzerinden sahabeden gelen rivâyetler çerçevesinde ortaya koymaktadır. Aynı şekilde Muhammed b. Ali eş-Şevkânî'nin (öl. 1250/1834) ed-Dürrü'n-Nadîd fì İhlâsi Kelimeti't-Tevhîd adlı eserini de bu bağlamda değerlendirmek mümkündür. ${ }^{2}$ Bununla birlikte İhlâs Sûresi'ne dair telif edilen çalışmalarda da müstakil olarak "ihlâs" kavramı ele alınmasa da ihlâsın mahiyeti hakkında malumat bulunmaktadır. Söz gelimi Muallim Nâci'nin (öl. 1310/1893) Hulâsatü'l-İhlâs adlı risâlesi İhlâs Sûresi'nin tefsiri hakkında zikredilmeye değerdir. ${ }^{3}$ Bu risâle hakkında daha sonra Ali Öztürk bir makale de hazırlamıştır. ${ }^{4}$ Muallim Nâci'nin risâlesinin yanı sıra farklı müelliflerin risâleleri de geç dönem araştırmacıları için çalışma konusu haline gelmiştir. Bu hususta "Kur'an'ın İlk Tercümeleri ve Mustafa b. Muhammed'in İhlâs Sûresi Tefsiri" 5 ve "Ekmelüddîn Bâbertî'nin İhlâs Sûresi'nin Tefsirine Dair Risâlesi Üzerine Bir Değerlendirme" ${ }^{\prime}$ başlıklı çalışmalarını misal vermek mümkündür. Ayrıca "İ̧sârî İhlâs Tefsiri Risâleleri"7 adlı makale de İhlâs Sûresi'nin işâri tefsiri hakkında detaylı bir literatür bilgisi mevcuttur. Ancak buraya kadar zikri geçen eserler muhtevaları gereği müstakil olarak "ihlâs" kavramına yoğunlaşmamışlardır.

Diğer taraftan "ihlâs" kavramına dair daha özel nitelikteki araştırmalar arasında konulu Kur'ân çalışmaları bulunmaktadır. Fakat bu kabilden çalışmalar daha çok kavramın geçtiği âyetlerle sınırlı kalmaktadır. Ayrıca Kur'ân kavramlarına dair semantik tahliller yapan eserlerde, müstakil olarak ihlâs kavramından ziyade ihlâsla ilgili bazı kavramların incelendiğini ifâde etmek mümkündür. Söz gelimi Kur'ân'da Dîn̂̂ ve Ahlâkî Kavramlar adlı eser ${ }^{8}$ bu bağlamda değerlendirilebilir. Ancak müstakil olarak ihlâs hakkında yapılan çalışmalar arasında Gülen Acar'ın Kur'ân-ı Kerîm'de İhlâs isimli yüksek lisans çalışması zikredilebilir.9 Araştırmamızın konusuyla yakından ilgili olan bu tez, kavramın sözlüklerdeki kullanımının yanı sıra Kur'ân âyetlerindeki geçiş şekillerini ortaya koymaya çalışmıştır. Ne var ki söz konusu çalışma sözlüklerle ilgili kısımda daha fazla sözlükten istifâde etmek ve Kur'ân âyetlerindeki manaları daha sistematik bir şekilde sunmak açısından geliştirilmeye muhtaç kalmaktadır. Aynı şekilde Ahmet Özdemir'in "Kur'ân'da İhlâs" başlıklı makalesi ${ }^{10}$ de kavramın tahlili hususunda bu araştırmamızın hedeflerini karşılayamamaktadır. Bunlara ilaveten "İhlâs Kavramının Semantik Analizi" başlıklı makalede ${ }^{11}$ kavram; sadece sözlükler değil aynı zamanda Kur'ân, hadis ve tasavvuf açısından ele alınmaktadır. Ancak makalenin sınırları gereği sözlük ve Kur'ân kısmı muhtasar olarak işlenmiştir. Öte yandan "Kur'ân'da İhlâs Kavramı ve Muhlis İnsanın Vasıfları" isimli makalede ${ }^{12}$ kavramın Kur'ân âyetlerindeki kullanım şekilleri hususunda niceliksel bilgi verilse de kavramın kök anlamı ve anlam alanlarının tasnifi sınırlı kalmaktadır.

\footnotetext{
${ }^{1}$ Ebü'l-Ferec Zeynüddîn Abdurrahman b. Ahmed b. Receb, Kelimetü'l-ïhlâs ve Tahkîku Ma'nâhâ (Beyrut: el-Mektebetü'l-İslâmî, 1397/1977), 7-71.

2 Ebû Abdullah Muhammed b. Ali eş-Şevkânî, ed-Dürrü'n-Nadîd fî İhlâsi Kelimeti't-Tevhîd (Mısır: Matba'atü'l-Menâr, 1340/1921), $2-42$.

${ }^{3}$ Muallim Nâci, Hulâsatü'l-ìlîs (Konstantiniye: Matbaatü Ebu'd-Diyâ, 1304/1886), 3-36.

${ }^{4}$ Ali Öztürk, “Muallim Nâci (1849-1893)'nin "Hülâsatü'l-İhlâs" İsimli İhlâs Sûresi Tefsiri”, İslâmî Ilimler Dergisi 7/2 (2012), 109139.

${ }^{5}$ Yusuf Akçay, “Kur'ân'ın İlk Tercümeleri ve Mustafa b. Muhammed'in İhlâs Sûresi Tefsiri”, Dil ve Edebiyat Araştırmaları Dergisi 5 (2012), 125-140.

${ }^{6}$ Ali Eroğlu, "Ekemelüddîn Bâbertî'nin İhlâs Sûresi'nin Tefsirine Dair Risâlesi Üzerine Bir Değerlendirme”, Ekmelüddin Bâbertî'yi Keşif Yolunda I. Ekmelüddîn Bâbertî Sempozyumu 28-30 Mayıs 2010, ed. Selçuk Coşkun (Erzurum: Bayburt Üniversitesi Yayınları 2014), 535-542.

7 Semih Ceyhan - İslim Gümüştekin, "İşâ̂î İhlâs Tefsiri Risâleleri”, Türkiye Araştırmaları Literatür Dergisi 15/30 (2017), 317-371.

${ }^{8}$ Toshihiko Izutsu, Kur'ân'da Dînî ve Ahlâkî Kavramlar, çev. Selahattin Ayaz (İstanbul: Pınar Yayınları, 2010), 197-371.

${ }^{9}$ Gülen Acar, Kur'ân-ı Kerîm'de İhlâs (Ankara: Ankara Üniversitesi Sosyal Bilimler Enstitüsü, Yüksek Lisans Tezi, 1995), 5-85.

${ }^{10}$ Ahmet Özdemir, Kur'ân'da İhlâs", Gazi Osman Paşa Üniversitesi İlahiyat Fakültesi Dergisi 3/2 (2015), 153-166.

${ }^{11}$ Yunus Ekin, "İhlâs Kavramının Semantik Analizi", Tasavvuf: İlmî ve Akademik Araştırma Dergisi 3/9 (2002), 147-160.

12 İsmail Karagöz, “Kur’ân’ da İhlâs Kavramı ve Muhlis İnsanın Vasıfları”, Diyanet İlmi Dergi 33/ 4 (1997), 69-84.
} 
İhlâs kavramı hakkında yapılan mezkûr çalışmalarda, gerek kavramın sözlük bilim açısından tahlili gerekse âyetlerdeki anlamlarının düzenli bir şekilde tasnifinin, bu araştırmamızda amaçladığımız düzeyde ele alınmadığı görülmektedir. Nitekim ihlâsla ilgili telif edilen eserlerde âyetlerdeki bazı hususlara işaret edildiği tespit edilmiştir. Ancak bu araştırmada söz konusu mesele, âyetler açısından tasnife tabi tutulacak ve farklı bağlamlarda zikredilen âyetler ortak bir anlam alanında ele alınacaktır. Bu nedenle araştırmamızda kavramın önce sözlük bilim açısından detaylı tahlili yapılacak, ardından da muhteva tahlili hususunda kavramın Kur'ân âyetlerinde geçiş şekillerine göre ikili bir tasnif önerilecektir. Böylelikle araştırmada sistematik analiz ile kavramın ifâde ettiği kök anlamların ve âyetlerdeki manaların kategorik bir şekilde ortaya çıkarılması amaçlanmaktadır.

\section{1. İhlâs Kavramının Anlamı}

İhlâs kavramı "حلص" kökünden türemiş olup bir şeyi, içine karışan ve değerini düşüren başka şeylerden temizleyip arındırmak ve saflaştırmak manalarına gelmekle birlikte samimiyeti ve gönülden bağlılığı ifâde etmektedir. ${ }^{13}$ Kavramın öncelikle Arap dilindeki kullanımları, ardından âyetlerdeki anlamları detaylandırılacaktır.

\subsection{Arap Dilinde “خلص"Maddesi}

Arap dilinde "خلص" maddesi, sözlüklerdeki fiil ve isim türevleri açısından değerlendirilebilir. Buna göre söz konusu maddenin fiil türevleri sülâsî mücerred ve sülâsî mezîd olmak üzere iki kısma ayrılmaktadır. Sülâsî mücerred olarak fiilin birinci ve dördüncü bâbta kullanıldığı görülmektedir. Bu

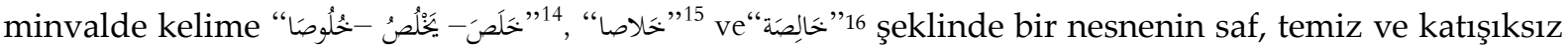
olması anlamına gelmektedir. ${ }^{17}$ Aynı zamanda kelime bu kullanımı ile kurtulup emniyette olmayı da

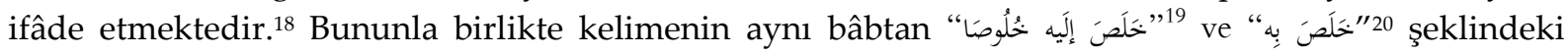
kullanımı ise "ulaştı" anlamına gelmektedir. Üstelik ulaşmanın zikri geçen hakikî anlamının yanı sıra

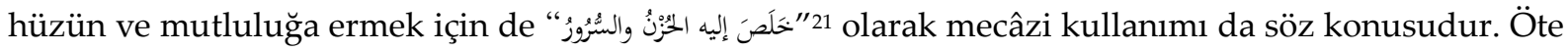

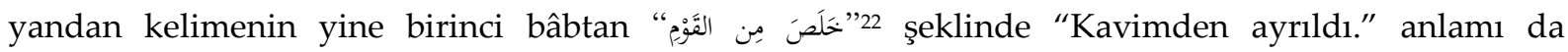
bulunmaktadır. Nitekim Hz. Peygamber'in dedesi Abdulmuttalib hakkındaki bir rivâyette bu kullanım görülmektedir. ${ }^{23}$ Rivâyete göre kıtlık ve kuraklık döneminde Rukayka binti Ebî Sayfî b. Hâşim rüyasında birinin Kureyşlilere hitaben kendisiyle bereket gelecek olan peygamberi müjdeleyip içlerinden birinin vasıflarını söyledikten sonra, vasıfları zikredilen kimse ve evlâdının insanların arasından ayrılıp öne çıkmalarını ve her kabileden bir kişinin de onlara eşlik edip Ebû Kubeys Dağı'na

\footnotetext{
${ }^{13}$ Muhammed b. Mükerrem b. Manzûr, Lisânü'l-'Arab (Beyrût: Dâru Sâdır, ts.), "hls", 7/26-29.

${ }^{14}$ Halîl b. Ahmed, Kitâbu'l-'Ayn (Beyrut: Mektebetü'l-Lübnan, 2004), "hls", 218; Ebû Bekr Muhammed b. Hasen b. Düreyd, Cemheratü'l-Lüga (Beyrut: Daru'l-i̇lm li'l-Melâyîn, 1987), "hls", 1/604; Ebû Nasr İsmâîl b. Hammâd el-Cevherî, es-Sihâh Tâcü'lLüga ve Sihâhü'l-'Arabiyye, thk. Ahmed Abdülğafûr 'Attâr (Kâhire: Dâru'l-ïlmi li'l-Melâyîn, 1399/1979), "hls", 3/1037; Ebû'lKâsım Cârullah Mahmûd b. Ömer ez-Zemahşerî, Esâsü'l-Belâga (Misır: Dâru'l-Kütüb, 1972), "hls", 1/245; İbn Manzûr, "hls", 7/26; es-Seyyid Muhammed Murtazâ ez-Zebîdî, Tâcu'l-'Arûs (Beyrût: Dâru'ș-Ṣâdır, 1306/1888), “hls”, 4/388; Ebû'l-Kemâl Ahmed Âsım Efendî, el-Ûkyânûsu'l-Besît fî Tercemeti'l-Kâmûsi'l-Muhît (İstanbul ts.), “hls”, 2/373.

15 İbn Düreyd, "hls", 1/604; İbn Manzûr, "hls", 7/26; Zebîdî, "hls", 4/389.

${ }^{16}$ Zebîdî, "hls", 4/388; Âsım Efendî, "hls", 2/373.

17 Âsım Efendî, "hls", 2/373.

${ }^{18}$ Halîl b. Ahmed, "hls", s.218; Zebîdî, "hls", 4/390; İbn Manzûr, "hls", 7/26, 27.

${ }^{19}$ Halîl b. Ahmed, "hls", s.218; Cevherî, "hls", 3/1037; Zemahşerî, "hls", 1/246; İbn Manzûr, "hls", 7/26; Zebîdî, "hls", 4/389; Âsım Efendî, "hls", 2/374.

${ }^{20}$ Zemahşerî, "hls", 1/246; İbn Manzûr, "hls", 7/26. Zebîdî, "hls", 4/389.

${ }^{21}$ Zemahşerî, "hls", 1/246; Zebîdî, "hls", 4/389.

22 Zemahşerî, "hls", 1/246; Zebîdî, "hls", 4/390.

${ }_{23}$ İbn Manzûr, "hls", 7/27.
} 
çıkıp dua etmelerini söylemiştir. Rukayka bu rüyasını anlattığında söz konusu vasıfları taşıyan kişinin Abdulmuttalib olduğu anlaşılmış ve Hz. Peygamber'in de bulunduğu bir grupla belirtilen mekânda

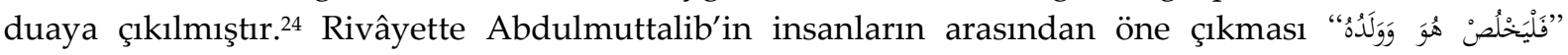

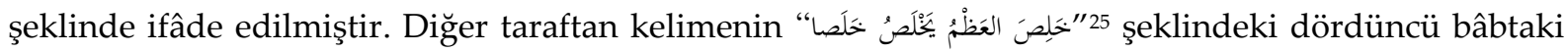
kullanımı ise el ve ayaktaki uzun kemiklerin ince filizler gibi olmasını ve etin kemikten ayrılmasını ifâde etmek için tercih edilmektedir.

"خلص” maddesinin sülâsî mezîd fiilleri ise altı farklı bâbta gelmektedir. Söz konusu bâbların ilki

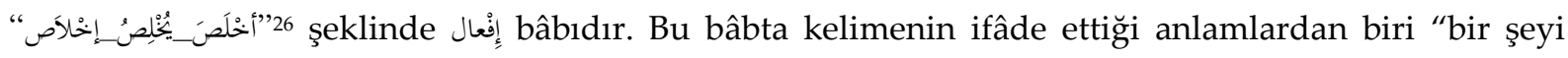

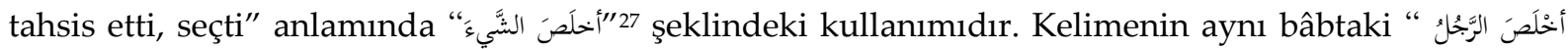
每” 28 şeklindeki kullanımı ise "bir kimse yağın özünü aldı” anlamına gelmektedir.29 Aynı şekilde bu bâbta kelimenin "devenin ilikli (ilikleri sağlam ve çok), semiz ve besili olması" anlamına gelen "

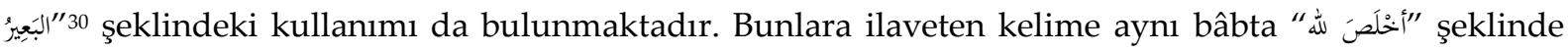
"ibadette riyayı bırakıp sadece sadece Allah'a ibadet etti" manasına gelmektedir. ${ }^{31} \mathrm{Bu}$ son kullanımı

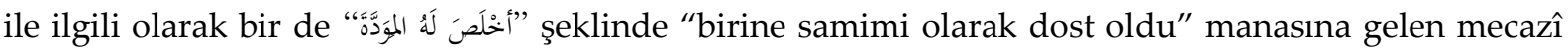
anlam da söz konusudur. ${ }^{32}$ Dolayısıyla zikri geçen bâbta kelimenin dört farklı kullanımının olduğu tespit edilmektedir.

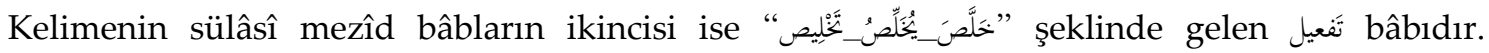

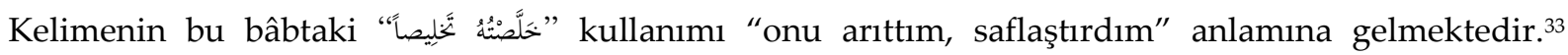

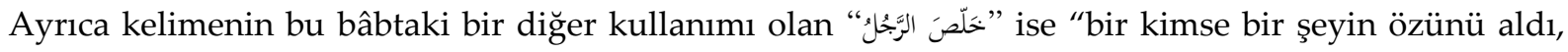
damıttı" anlamını ifâde etmektedir. ${ }^{34}$ Bunlara ilaveten "bir kişi birine ücretini, mislini verdi"

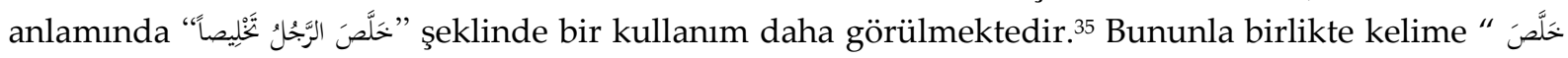

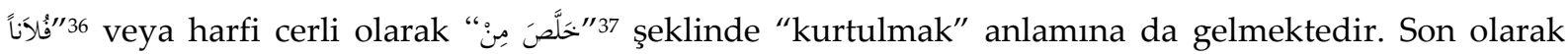

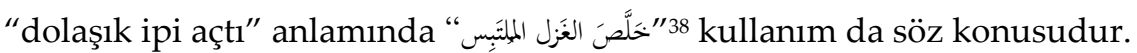

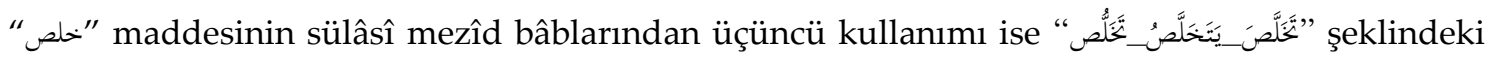

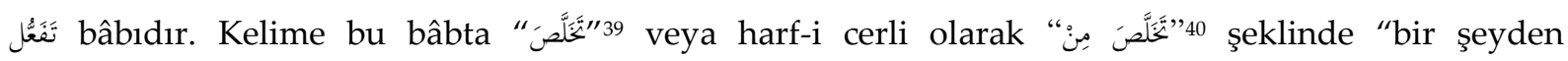

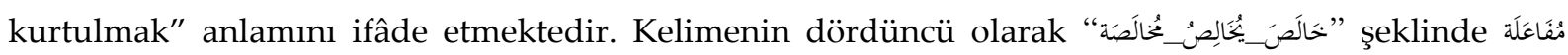

${ }^{24}$ Ebü'l-Kâsım Süleymân b. Ahmed b. Eyyûb et-Taberânî, el-Mu'cemü'l-Kebîr, nşr. Hamdi Abdülmecîd es-Selefî (Kahire: Mektebetü İbn Teymiyye, 1404/1984), 24/259, 260, (no. 661).

25 İbn Manzûr, "hls", 7/29. Zebîdî, "hls", 4/389; Âsım Efendî, "hls", 2/374.

${ }^{26}$ Halîl b. Ahmed, "hls", s. 219; İbn Düreyd, "hls", 1/604; Cevherî, "hls", 3/1037; Zemahşerî, "hls", 1/246; İbn Manzûr, "hls", 7/26;

Zebîdî, "hls", 4/388-389; Âsım Efendî, "hls", 2/374.

27 Âsim Efendî, "hls", 2/374.

28 "Adam yağın özünü aldı."

29 İbn Manzûr, "hls", 7/28; Zebîdî, "hls", 4/390; Âsım Efendî, "hls", 2/374.

30 İbn Manzûr, "hls", 7/28; Zebîdî, "hls", 4/390; Âsım Efendî, "hls", 2/374.

${ }^{31}$ Halîl b. Ahmed, "hls", s. 219; Cevherî, "hls", 3/1037; Zemahşerî, "hls", 1/245; İbn Manzûr, "hls", 7/26; Zebîdî, "hls", 4/390; Âsım Efendî, "hls", 2/374.

32 İbn Düreyd, "hls", 1/604; Zemahşerî, "hls", 1/246; İbn Manzûr, "hls", 7/26; Zebîdî, "hls", 4/390.

33 İbn Düreyd, "hls", 1/604; Zemahşerî, "hls", 1/246; İbn Düreyd, "hls", 1/604.

34 Zebîdî, "hls", 4/390; Âsım Efendî, "hls", 2/374.

35 İbn Manzûr, "hls", 7/28; Zebîdî, "hls", 4/390; Âsım Efendî, "hls", 2/374.

36 Zebîdî, "hls", 4/390; Âsım Efendî, "hls", 2/374.

${ }^{37}$ Halîl b. Ahmed, “hls”, s. 219 Ebû'l-Huseyn ez-Zekeriyya Ahmed b. Fâris, Mücmelü'l-lüga (Beyrut Müessesetü'r-Risâle, 1984),

"hls", 299; Cevherî, "hls", 3/1037; İbn Manzûr, "hls", 7/26.

38 Zemahşerî, "hls", 1/246.

${ }^{39}$ Halîl b. Ahmed, "hls", s. 219; İbn Manzûr, "hls", 7/26; Zebîdî, "hls", 4/390; Âsım Efendî, "hls", 2/374.

40 İbn Düreyd, "hls", 1/604; Zemahşerî, "hls", 1/246. 
bâbında kullanımı "samimi ve içten olmak, dostluk kurmak, kavgasız iyi geçinmek" manalarına gelmektedir. ${ }^{41}$ Bunların yanı sıra kelimenin sülâsî mezîd bâblardaki beşinci kullanımı ise

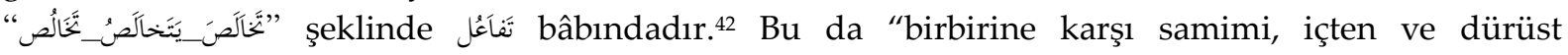
davranmak" anlamın ifâde etmektedir. Son olarak kelime " șeklinde altınc1

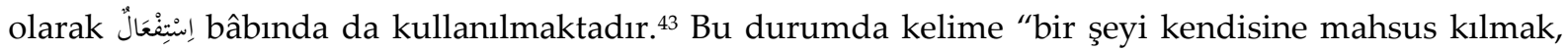
kendisine seçmek" anlamına gelmektedir.

"خلص” maddesinin sözlüklerdeki isim kullanımları ise 18 farklı formda görülmektedir.

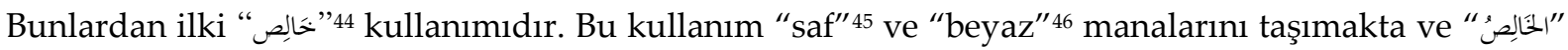
şekliyle Bağdat’ın doğusunda büyük bir mahalle veya bir nehrin adı için kullanılmaktadır. ${ }^{47}$

Maddenin "خَالِصَّة" ikinci formu ise birinci bâbın masdarı olarak kullanılıp, if'âl bâbının mastar1"88 ile de aynı anlamı taşımaktadır. Bunların yanı sıra kelime bu haliyle ism-i fâilin müennes çekiminde "saf" 49 olmak anlamına gelmektedir. Ayrıca kelimenin "filanca bana karşı karşı dürüst ve samimidir"

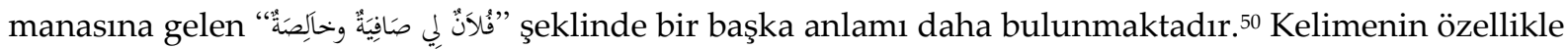

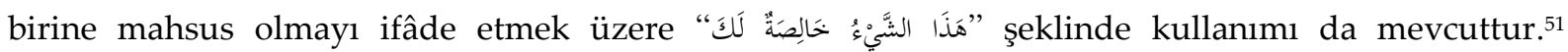
Sözlüklerde bu son iki kısma giren âyetlerdeki kullanımlarla ilgili tefsir kabilinden bilgiler de verilmektedir. ${ }^{52}$ Ayrıca bu formuyla kelime "arkadaş, samimi dost" anlamlarına da gelmektedir. ${ }^{53}$ Bütün bunlara ilaveten kelimenin, Sicilya adasındaki bir belde, ${ }^{54}$ Ecfer ile Huzeymiye arasındaki bir küçük göl, ${ }^{55}$ Şamlıların giydiği bir elbise ${ }^{56}$ ve bir kadının ismi ${ }^{57}$ olarak taşıdığı manalar da dile getirilmektedir.

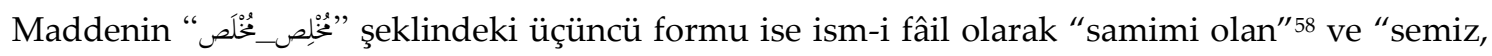
yağl1"59; ism-i mefûl olarak ise "seçilen"60 anlamını ifâde etmektedir. Aynı şekilde maddenin

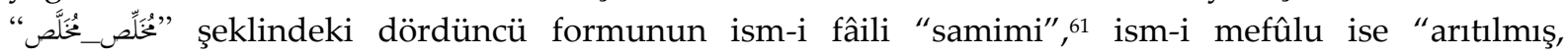
saflaştırılmış"62 anlamındadır. Öte yandan maddenin beşinci formu olan " pişiririlmiş hurmadan çıkan özlü su",63 "pişirilen yağdan çıkan öz" ${ }^{64}$ ve "sütün yağı"65 anlamlarında da kullanılmaktadır.

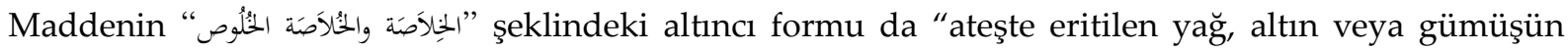

${ }^{41}$ Cevherî, "hls", 3/1037; İbn Manzûr, "hls", 7/27; Zebîdî, "hls", 4/390; Âsım Efendî, “hls", 2/374.

42 Zemahşerî, "hls", 1/246; İbn Manzûr, "hls", 7/27; Zebîdî, "hls", 4/390.

${ }^{43}$ Cevherî, "hls", 3/1037; Zemahşerî, “hls", 1/245-246; İbn Manzûr, "hls", 7/28; Zebîdî, "hls", 4/390; Âsım Efendî, "hls", 2/374.

${ }^{44}$ Halîl b. Ahmed, "hls", s. 219; Zemahşerî, "hls", 1/246, İbn Manzûr, "hls", 7/28.

${ }^{45}$ Zemahşerî, "hls", 1/246; Zebîdî, "hls", 4/389; Âsım Efendî, "hls", 2/373-374.

46 Zemahşerî, "hls", 1/246; İbn Manzûr, "hls", 7/29; Zebîdî, "hls", 4/389

47 Zebîdî, "hls", 4/389; Âsım Efendî, "hls", 2/374.

48 İbn Manzûr, "hls", 7/26; Zebîdî, "hls", 4/390.

49 İbn Manzûr, "hls", 7/27; Zebîdî, "hls", 4/389; Âsım Efendî, "hls", 2/374.

${ }^{50}$ Halîl b. Ahmed, "hls", s. 219.

51 İbn Düreyd, "hls", 1/604; Zemahşerî, "hls", 1/246; İbn Manzûr, "hls", 7/27.

52 İbn Manzûr, "hls", 7/27; Zebîdî, "hls", 4/389; Âsım Efendî, "hls", 2/374.

${ }^{53}$ Halîl b. Ahmed, "hls", s. 219; Zemahşerî, "hls", 1/246; İbn Manzûr, "hls", 7/28; Zebîdî, "hls", 4/390.

${ }^{54}$ Zebîdî, "hls", 4/389; Âsım Efendî, "hls", 2/374.

55 Zebîdî, "hls", 4/389; Âsım Efendî, "hls", 2/374.

56 İbn Manzûr, "hls", 7/28, 29.

57 İbn Manzûr, "hls", 7/29; Zebîdî, "hls", 4/390.

58 İbn Düreyd, "hls", 1/604; Zemahşerî, "hls", 1/246; İbn Manzûr, "hls", 7/26; Zebîdî, "hls", 4/389, 390.

${ }^{59}$ Halîl b. Ahmed, "hls", s. 219; İbn Manzûr, "hls", 7/26.

${ }^{60}$ Halîl b. Ahmed, "hls", s. 219; İbn Manzûr, "hls", 7/26.

${ }^{61}$ Zemahşerî, "hls", 1/246.

62 Zemahşerî, "hls", 1/246; Zebîdî, "hls", 4/390.

${ }^{63}$ Halîl b. Ahmed, "hls", s. 219.

64 İbn Manzûr, "hls", 7/27.

${ }^{65}$ Halîl b. Ahmed, "hls", s. 219. 
çökeltisi" anlamında kullanılmaktadır. ${ }^{66}$ Benzer şekilde "çökeltiden altta kalan" anlamına gelen "الإنْالَص و الإخْلاًَةَ" da yedinci formu teşkil etmektedir.67 Bunların yanı sıra yağın dibinde kalan tortu için " kelimesi de sekizinci form olarak ortaya çıkmaktadır. ${ }^{68}$ Maddenin dokuzuncu formu olan “ olan kayışların aralığından süzülüp akan suyu ifâde etmektedir. On birinci form olan "الحئيَّ" ise "Usfan ile Kudeyd arasında bir kale ismi" ve "beyaz" anlamlarına gelmektedir.71

Maddenin diğer formları ise "bir tür sarmaşık" ve "Müzeyne'de bir yer" anlamına gelen

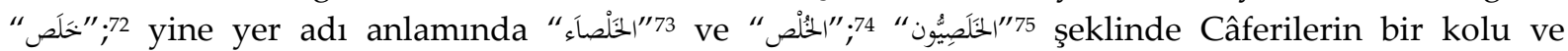
"Halasa"76 şeklinde özel isim olarak kullanılmıştır. Ayrıca kelimenin terkip olarak sırasıyla "Kelime-i

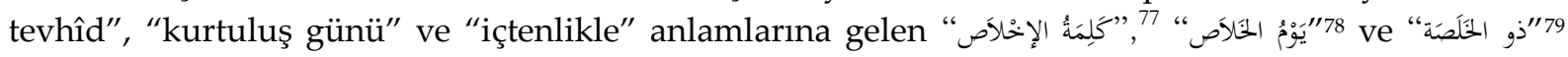
şeklinde kullanımları da mevcuttur. Bu kullanımları hakkında sözlüklerdeki malzeme son derece detaylıdır. Netice itibariyle "خلص" maddesi gerek fiil gerekse isim kullanımları açısından sözlüklerde geniş bir anlam alanına sahiptir. Nitekim kelimenin fiil kullanımlarından sülâsi mücerrred bâbtaki formları saf ve katışıksız olmak, ulaşmak gibi manalarda kullanıldığı gibi mecâzi olarak mutluluğa ulaşmak anlamında da dile getirilmiştir. Ayrıca kelimenin bu haliyle "ayrılmak" anlamı da bulunmaktadır. Dolayısıyla kelimenin mücerred kullanımında ayrıştırmak manası öne çıkmaktadır. Bu bir nesne söz konusu olduğunda fiziksel olarak ayırıp özünü almayı, bir kişi olduğunda ise kişinin diğerlerinden ayrılmasını ifâde etmektedir. $\mathrm{Bu}$ ayrılık ise fiziksel olarak mekândan ayrılmak olabileceği gibi biriyle ilişkisini kesmeyi de ifâde etmektedir. Aynı şekilde kelimenin kök anlamlarından "ulaşmak" da hakikî ve mecâzî manada gelebilmektedir.

Kelimenin mezîd bâblarından ilki olan if'âl bâbındaki kullanımı da hakikî anlamıyla bir şeyin özünü almayı, mecâzî olarak ise birine kaşrı samimi olmayı ifâde etmektedir. Buna ilaveten kelimenin tef'îl bâbındaki kullanımı fiziki olarak bir şeyin arıtılması, dolaşık ipin açılması gibi manalara gelirken mecâzî olarak da kurtulmayı ifâde etmektedir. Öte yandan kelimenin tefa'ul bâbındaki formu kurtulmak ve birine dürüst davranmak anlamına gelmektedir. Bu formun ikinci anlamı tefấul bâbında da karşılıklı samimiyeti göstermektedir. Mezîd fiillerini son kullanım şekli olan istif'âl bâbında ise bir şeyi kendisine has kılma öne çıkmaktadır. Dolayısıyla fiil kullanımları mezîd bâblarda kök anlamıyla bağlantılı bir şekilde hakîki ve mecazi olarak kullanılmaktadır. Aynı durum isim kullanımları için de söz konusudur.

\footnotetext{
${ }^{66}$ Daha detaylı anlamlar için bk. Halîl b. Ahmed, "hls", s. 219; Ahmed b. Fâris, "hls", 299; İbn Düreyd, "hls", 1/604; Cevherî, "hls", 3/1037; Zemahşerî, "hls", 1/245, İbn Manzûr, "hls", 7/28; Zebîdî, "hls", 4/389; Âsım Efendî, "hls", 2/374.

${ }^{67}$ Ahmed b. Fâris, "hls", 299; İbn Manzûr, "hls", 7/28; Zebîdî, "hls", 4/389.

68 Âsım Efendî, "hls", 2/374.

${ }^{69}$ Zebîdî, "hls", 4/389; Âsım Efendî, "hls", 2/374.

70 Zebîdî, "hls", 4/389; Âsım Efendî, "hls", 2/374

71 Zebîdî, "hls", 4/389; Âsım Efendî, "hls", 2/374.

72 İbn Manzûr, "hls", 7/28; Zebîdî, "hls", 4/389; Âsım Efendî, "hls", 2/374.

73 Halîl b. Ahmed, "hls", s. 219; İ̉n Düreyd, "hls", 1/604; Cevherî, "hls", 3/1037; Ahmed b. Fâris, "hls", 299; İbn Manzûr, "hls", 7/29; Zebîdî, "hls", 4/389; Âsım Efendî, "hls", 2/374.

74 Zebîdî, "hls", 4/390.

75 Zebîdî, "hls", 4/390.

${ }^{76}$ Zebîdî, "hls", 4/390.

77 İbn Düreyd, "hls", 1/604; Zemahşerî, "hls", 1/246; İbn Manzûr, "hls", 7/26; Zebîdî, "hls", 4/390.

78 Zebîdî, "hls", 4/390.

79 İbn Düreyd, “hls", 1/604; Cevherî, “hls", 3/1038; İbn Manzûr, “hls", 7/29; Zebîdî, “hls", 4/389; Âsım Efendî, “hls", 2/374.
} 


\subsection{Kur'ân'da "خلص" Maddesi}

Kur'ân-1 Kerîm'de "خلص" maddesi yedi farklı mâna ile on yedi sûrenin otuz bir farklı yerinde geçmektedir. ${ }^{80}$ Maddenin fiil türevleri sülâsî mücerred ve mezîd fiiller olmak üzere iki kısımda değerlendirilebilir. Bu bağlamda madde Kur'ân'da sülâsî mücerred olarak sadece " "نََّ" şeklinde yer almaktadır. Söz konusu âyet Hz. Yusuf'un kardeşleri hakkında olup şu şekildedir:

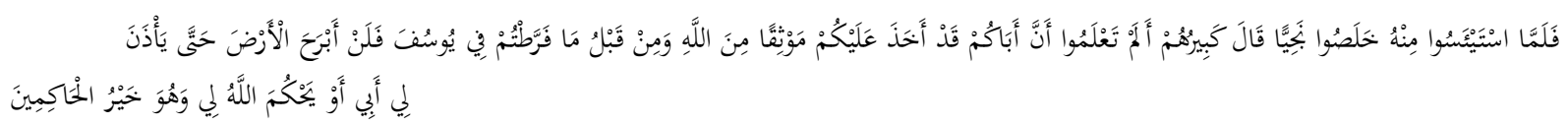

"Yûsuf'un onu vermesinden ümitlerini kestikleri zaman, (meseleyi) gizli görüşmek üzere ayrllıp (bir kenara) çekildiler. Büyükleri dedi ki: "Babanızın sizden Allah adına söz aldı̆̆ını ve daha önce de Yûsuf hakkında işlediğiniz kusuru bilmiyor musunuz? Artık babam bana izin verinceye veya Allah hakkımda hükmedinceye kadar buradan bir adım dahi atmam. O, hüküm verenlerin en hayırlısıdır."

Zikredilen âyete göre Hz. Yûsuf'un kardeşleri Bünyâmin'i geri getireceklerine dair babalarına söz vermelerine rağmen hırsızlık durumu nedeniyle ahitlerinde duramayacaklarını anlayıp, umutlarını kestiklerinde aralarında konuşmak üzere insanlardan uzaklaşarak kenara çekilmişlerdir. İçlerinden en büyük olanı kendileri adına bir af ve suçsuzlukları anlaşılması için orada kalarak kardeşlerine Bünyâmîn ile ilgili durumu babalarına anlatmalarını istemiştir. ${ }^{82}$ Âyette bu durum anlatılırken "kendi aralarında görüşmek üzere bir kenara çekildiler" ifâdesi yer almaktadır.

" maddesinin sülâsî mezîd fiileri ise sadece if âl ve istif'âl bâblarında gelmektedir. Madde

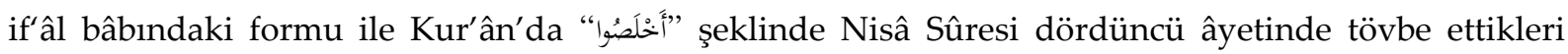

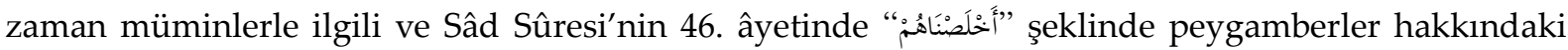

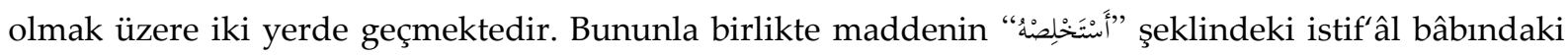
tek kullanımı da yine Yusuf Sûresi'nin şu âyetinde gelmektedir:

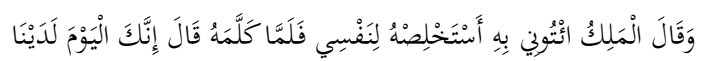

“Hükümdar 'Onu yanıma getirin, kendime özel danışman edineyim' dedi. Onunla konuştuktan sonra da: 'Sen artık bundan böyle, nezdimizde yüksek mevkili ve güvenilir birisin' dedi." 83

Âyette zikredildiğine göre hükümdar Yûsuf'a bazı hasletleri hasebiyle itimat etmiştir. Hz. Yûsuf da hükümdardan devletin hazinelerinin sorumluluğunu istemiştir. ${ }^{84}$

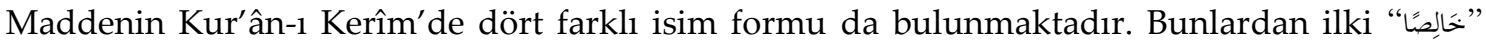
kelimesidir. Bu kelime hakikî ve mecazî anlamda geçmektedir. Nitekim şu âyeti, kelimenin hakikî manası açısından değerlendirmek mümkündür:

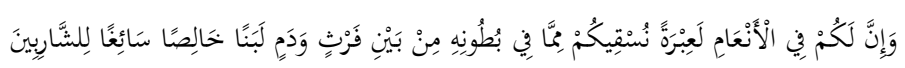

"Elbette hayvanlarda da siz için ibretler vardır. Onların karınlarındaki fışkı ile kan arasından; size, içenlerin boğazından kolaylıkla geçen dupduru bir süt içiririz." 85

Âyette Allah Teâlâ kudretine işaret ederken hayvanların karınlarındaki dışkı ile kan arasından beyazlığı, kokusu ve tatlılığı ile dupduru süt çıkardığını buyurmaktadır. Bu âyetin öncesinde gökten

\footnotetext{
${ }^{80}$ Muhammed Fuâd Abdülbâkî, el-Mu'cemu'l-Müfehres li Elfâzi'l-Kur'âni'l-Kerîm (Mısır: Dâru'l-Kütüb, 1945), 238.

${ }^{81}$ Yûsuf $12 / 80$.

${ }^{82}$ Ebü'l-Fidâ İbn Kesîr, Tefsîru'l-Kur'âni'l-Azîm (Beyrut: Dâru'l-Kütübi'l-ilmiyye, 1998), 4/346.

83 Yûsuf 12/54.

84 İbn Kesîr, Tefsîru'l-Kur'âni'l-Azîm, 4/338-339.

85 en-Nahl 16/66.
} 
yağmur yağdırıp kupkuru yeri diriltmesi; âyetin devamında ise insanların içecek ve güzel gıdalar elde ettikleri meyvelerde yine Allah'ın kudretine ibretler olduğu vurgulanmaktadır. ${ }^{86}$ Bununla birlikte maddenin isim formlarından olan "خَالِصَّ" kelimesi mecazî anlamda şu âyette geçmektedir:

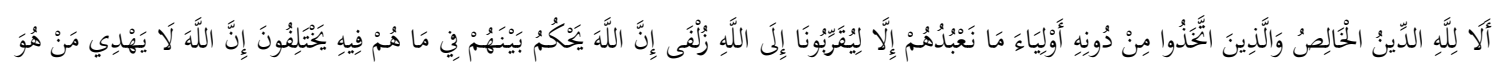
كَاذِبْ كَنَّارُ

"Haberiniz olsun ki; halis din yalnızca Allah'a mahsustur. O'ndan başka bir takım dostlar edinenler (şöyle derler): 'Biz onlara sadece bizi Allah'a daha çok yaklaştırsınlar diye ibadet ediyoruz.' Doğrusu Allah, ihtilafa düştükleri şeylerde, aralarında hüküm verecektir. Muhakkak ki Allah; yalancı, kâfir kimseyi hidâyete eriştirmez." ${ }^{87}$

Âyette din mecâzî isnad ile sahibinin sıfatıyla vasıflanmıştır. ${ }^{88}$ Burada mana ise "Ey insanlar! Uyanınız, hakikî, Allah'ın rızasına uygun, şirk ve riya şüphesinden uzak olan din, Allah Teâlâ'nın kabul buyurmuş olduğu İslâm dinidir, o tevhîd dinidir. Binaenaleyh ondan başka hakikî bir din yoktur ve o ezelî mabûddan başka ibadet ve itaate lâyık bir yaratıcı mevcut değildir. İlahlık sıfatlarında tek olan, ancak O'dur." şeklindedir. ${ }^{89}$

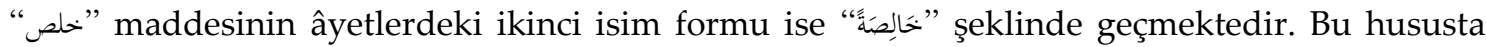
geçen dört âyet şu şekilde sıralanabilir:

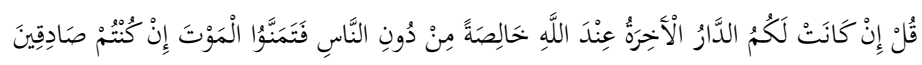

"Ĕger ahiret yurdu Allah katında başkalarına değil de yalnız size mahsus ise ve bu iddianızda samimi iseniz haydi ölümü temenni edin!"90

Âyet Yahudilere meydan okumaktadır. Nitekim Yahudiler Allah Resûlü ile ilgili bilgilerine rağmen onu inkâr ettiklerinden ölümü temenni etmeyeceklerdir. ${ }^{91}$ Cuma Sûresi'ndeki "De ki: Ey Yahudiler! Bütün insanlar değil de, yalnız kendinizin Allah'ın dostları olduğunuzu iddia ediyorsanız, bunda da samimi iseniz, haydi ölümü temenni edin! Ama onlar, önceden yaptıklarından dolayı ölümü asla temenni etmezler. Allah, zalimleri çok iyi bilir. De ki: Sizin kendisinden kaçtığınız ölüm, muhakkak sizi bulacaktır. Sonra da görüleni ve görülmeyeni bilen Allah'a döndürüleceksiniz de O size bütün yaptıklarınızı haber verecektir."92 âyeti de bu anlamı desteklemektedir. Konuyla ilgili bir başka âyette Allah Teâlâ şöyle buyurmuştur:

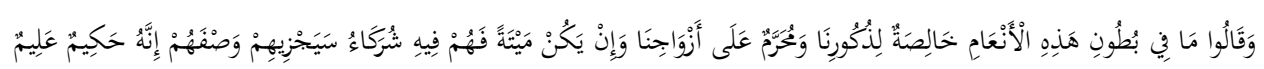

"Dediler ki: 'Bu hayvanlarn karmlarnndakiler sadece erkeklerimize ait olup hanımlarmıza haram kılınmıştır. Ĕ̆ger (hayvanın yavrusu) ölü doğarsa hepsi ona ortak olur.' Allah, onların bu tür nitelemelerinin cezasinı verecektir. Muhakkak ki O, hikmet sahibidir, her şeyi bilendir." ${ }^{93}$

Âyet hakkındaki rivâyetlerde âyette kastedilenin süt olduğu ifâde edilmektedir. Nitekim Araplar sütü hanımlarına haram kılıp erkeklerine içirirler, deve veya koyun eğer erkek doğurursa onu keserler ve bu erkeklere ait olurdu, şâyet dişi doğurursa onu kesmezlerdi ancak ölü doğurursa onda

\footnotetext{
86 İbn Kesîr, Tefsîru'l-Kur'âni'l-Azîm, 4/498.

87 ez-Zümer 39/3.

${ }^{88}$ Ebû'l Kâsım Cârullah Mahmûd b. Ömer ez-Zemahşerî, el-Keşşâf 'an Hakâiki't-Tenzîl ve 'Uyûni Ekâvîl fî Vücûhi't-Te'vîll, thk. Adil Ahmed Ebû'l-Mevcûd - Ali Muhammed Muavvid (Riyâd: Mektebetü'l-Ubeykân, 1418/1998), 5/286.

89 Ömer Nasûhî Bilmen, Kur'ân-ı Kerîm Meâli Âlisi ve Tefsiri, sad. Muhsin Demirci, Sadrettin Gümüşs (İstanbul: İpek Yay., ts.), $6 / 333$.

90 el-Bakara 2/94.

${ }^{91}$ Muhammed b. Cerîr et-Taberî, Câmiu'l-Beyân 'an Te'vîli Âyi'l-Kur'ân, thk. Abdullah b. Abdulmuhsin et-Türkî (Kahire: Hicr, 1422/2001), 2/273; İbn Kesîr, Tefsîru'l-Kur'âni'l-Azîm, 1/220, 221.

92 el-Cum'a 62/6-8.

${ }^{9}$ el-En'âm 6/139.
} 


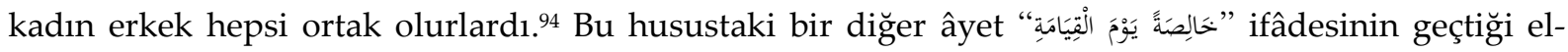
A'râf Sûresi'nin 32. âyetidir. ${ }^{95}$ Âyette istifham-ı inkârî ile Allah'ın çıkardı̆̆ı zînetleri ve temiz şeyleri haram kılan kimseler kastedilmektedir. Ayrıca kıyamet gününde nimetlerin sadece müminlere

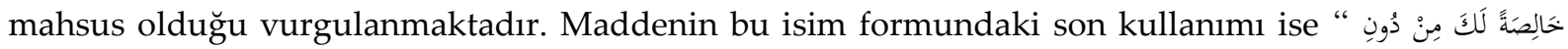

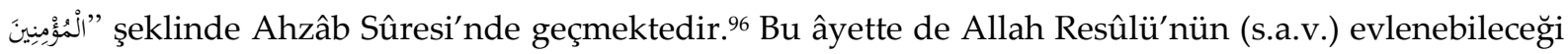
hanımlar zikredilirken diğer müminlerden farklı olarak bir kadının kendisini Hz. Peygamber'e velisiz ve mehirsiz hibe edebileceği bildirilmektedir. ${ }^{97}$

"خلص" maddesinin âyetlerdeki üçüncü isim formu ise " "خطُ

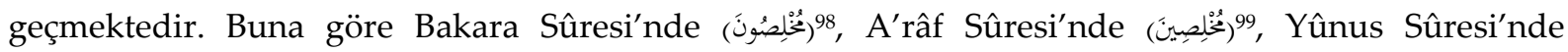

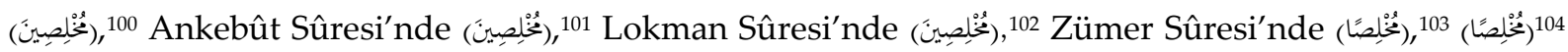

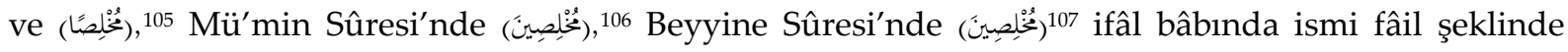
gelmiştir. Bakara Sûresi'ndeki âyette Allah Teâlâ Hz. Peygamber'e hitaben Yahudi ve Hristiyanlara, onların yaptığı gibi Allah'a şirk koşmadıklarını, bilakis ibadeti sadece Allah'a has kıldıklarını belirtmesini emretmektedir. Zira Yahudiler buzağıya taparak, Hristiyanlar ise Mesih'i ilah addederek Allah'a ortak koşmuşlardır. ${ }^{108}$ A'râf Sûresi'nde ise yine Hz. Peygamber'e hitaben kendisinin Allah'a yalan isnad edenlere nasıl cevap vereceği belirtilmekte ve bu bağlamda dini ve itaati sadece Allah'a has kılmak emredilmektedir. ${ }^{109}$ Öte yandan Yûnus Sûresi'nde musibet anından kurtulmak isteyenler, Allah'ın kendilerini kurtarması halinde hiç kimseyi O'na ortak koşmayacaklarını ve ibadeti sadece O'na mahsus kılacaklarını vaat etmektedirler. ${ }^{110}$ Aynı şekilde Ankebût Sûresi'nde de müşriklerin sıkıntı anında Allah'a şirk koşmamayı ifâde etmelerine rağmen kurtulduktan sonra yine ortak koşmaları anlatılmaktadır. ${ }^{111}$ Bunlara ilaveten Lokman Sûresi'nde de gemidekilerin, dalgalar etraflarını sardığında Allah'a samimi bir şekilde yalvarmaları ve karaya oturduktan sonraki durumlarından bahsedilmektedir. Diğer âyetlerden farklı olarak burada karaya oturunca hepsinin şirk üzere olmadığı ve içlerinde şükredenlerin de bulunduğu belirtilmektedir. ${ }^{112}$ Bu hususta Zümer Sûresi'nde gelen âyetlerde ise Kur'ân'ın Allah katından indirildiğinde dikkat çekildikten sonra Allah'a hiçbir şeyi ortak koşmadan sadece O'nun için amel etmek anlamında dinin Allah'a has kılınması emredilmektedir. ${ }^{113}$ Mü'min Sûresi'nin 14. âyetinde ise müşriklere muhalefet ederek dini Allah'a has

${ }_{94}$ Ebû Abdillâh Muhammed b. İsmâil el-Buhârî, el-Câmiu's-sahîh, nşr. Ebû Suheyb el-Kermî (Riyad: Beytü'l-Efkâri'd-Devliyye li'n-Neşr, 1419/1998), "Menâkib", 9 (no. 3521); İbn Hacer el-Askalânî, Fethu'l-Bârî bi Şerhi Sahîhi'l-Buhârî, nşr. Ebû Kuteybe Nazar Muhammed el-Faryâbî (Riyad: Dâru Taybe, ts.), 1/209; Taberî, Câmiu'l-Beyân, 9/584-589; İbn Kesîr, Tefsîru'l-Kur'âni'l-Azîm, 3/311. ${ }^{95}$ el-A' râf 7/32.

${ }^{96}$ el-Ahzâb 33/50.

97 el-Ahzâb 33/50.

${ }^{98}$ el-Bakara 2/139.

99 el-A'râf 7/29.

100 Yûnûs 10/22.

101 el-Ankebût 29/65.

102 Lokmân 31/32.

103 ez-Zümer 39/2.

104 ez-Zümer 39/11.

105 ez-Zümer 39/14.

${ }^{106}$ Mü'min 40/14, 65.

${ }^{107}$ Beyyine 98/5.

108 Taberî, Câmiu'l-Beyân, 2/608.

109 Taberî, Câmiu'l-Beyân, 10/141.

110 İbn Kesîr, Tefsîru'l-Kur'âni'l-Azîm, 4/226.

111 İbn Kesîr, Tefsîru'l-Kur'âni'l-Azîm, 6/264, 265.

112 İbn Kesîr, Tefsîru'l-Kur'âni'l-Azîm, 6/313, 314.

113 İbn Kesîr, Tefsîru'l-Kur'âni'l-Azîm, 7/74, 79, 80. 
kılmak buyrulmaktadır.114 Beyyine Sûresi'ndeki âyette de aynı bağlam, tevhid inancını benimseyen haniflerle irtibatlı olarak zikredilmiştir. ${ }^{115}$

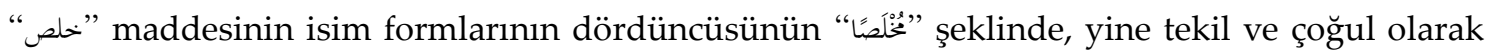

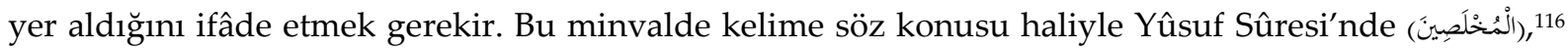

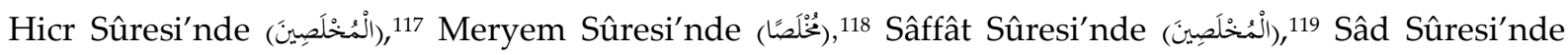

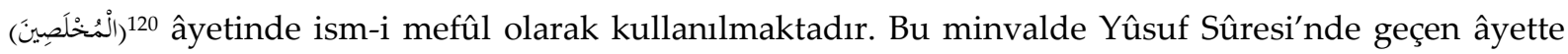
Hz. Yûsuf ile hükümdarın hanımı arasında geçen hadisede kendisinin günaha girmekten korunması hususu zikredilmekte ve Hz. Yûsuf'un tevhidi ve ibadeti sadece Allah'a has kılan kullardan olduğu,

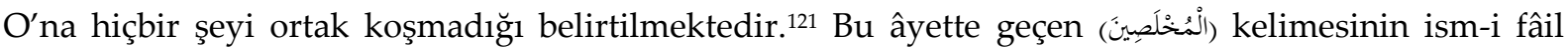
olarak okunmasının yanı sıra ikinci bir kıraat şekli olarak ism-i mefûl şeklinde okunduğu, bu durumda mananın onun nübüvvet vasıtasıyla Allah'ın seçkin kullarından olduğu belirtilmektedir. Her iki kıraatin manası da birbirine yakındır.122 Hicr Sûresi'ndeki âyette ise İblis'in insanlara yeryüzündeki kötülükleri güzel göstermek için vaadini dile getirirken içlerinden çok azını istisna etmesi zikredilmektedir. ${ }^{123}$ Meryem Sûresi'ndeki âyette ise ulu'l-azim peygamberlerinden olan Hz. Musa'nın Allah'ın insanlar arasında seçilmiş olan kullarından olduğu belirtilmektedir. Bu âyette

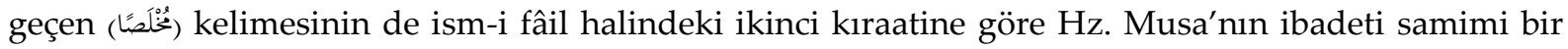
şekilde yaptığı ifâde edilmektedir. ${ }^{124}$ Diğer taraftan Sâffât Sûresi'ndeki 40. âyette Allah Teâlâ insanları azabı ile uyarırken salih amel işleyen muhlis kulları istisna etmiştir. ${ }^{125}$ Aynı sûrenin 74. âyetinde ise Allah'ın uyarıcı peygamberler göndermesine rağmen peygamberlerin kavimleri tarafından yalanmaları üzerine içlerinde sadece muhlis kulların kurtulduğu belirtilmektedir. ${ }^{126}$ Sûrenin 128. âyetinde de Hz. İlyas'ın kavmine Allah'a ibadeti tebliğ etmesine rağmen içlerinden çok azı hariç kavminin kendisini yalanladığı ifâde edilmektedir, muhlis olanlar bu azınlığı teşkil etmektedir. Âyette zikredilen kavmin İsrailoğulları olduğuna ve Hz. İlyas ile Hz. İdris'in kastedildiğine dair rivâyetler mevcuttur. ${ }^{127}$ Saffât Sûresi'nin 160. âyetinde ise Allah'ın kendisine evlad isnat edilmekten ve bunun gibi şanına yakışmayan şeylerin ileri sürülmesinden münezzeh olduğu ve muhlis olanların dışındakilerin bu iftiralarından dolayı azap göreceği ifâde edilmektedir. Âyette muhlis olanlarla gönderilmiş peygambere hak olarak indirilene tâbi olanlar kastedilmektedir. ${ }^{128}$ Son olarak Sâd Sûresi'ndeki âyet ise İblis'in insanlardan çok azını saptırmayacağı hakkındadır. ${ }^{129}$

"خلص" maddesi sözlüklerde "ihlâs" kavramı da dâhil geniş bir anlam alanında izah edilmektedir. Ancak Kur'ân'ı Kerîm'de söz konusu maddenin muhtelif âyetlerde sözlüklere nazaran çok daha sınırlı bir alanı olduğunu ifâde etmek mümkündür. Bununla beraber kelimen kökünün gerek fiil gerekse isim formlarında farklı ve yakın anlamların bulunduğu ifâde edilebilir. Nitekim kelimenin fiil olarak sülasî mücerred kullanımı fiziksel olarak bir mekândan ayrılmayı ifâde ederken,

\footnotetext{
114 İbn Kesîr, Tefsîru'l-Kur'âni'l-Azîm, 7/121.

115 İbn Kesîr, Tefsîru'l-Kur'âni'l-Azîm, 8/338.

116 Yûsuf 12/24.

117 el-Hicr $15 / 40$.

118 Meryem 19/51.

119 es-Saffât 37/40, 74, 128, 160.

120 Sâd 38/83.

121 Taberî, Câmiu'l-Beyân, 13/100, 101.

122 Taberî, Câmiu'l-Beyân, 13/100, 101.

${ }^{123}$ İbn Kesîr, Tefsîru'l-Kur'âni'l-Azîm, 4/459.

124 İbn Kesîr, Tefsîru'l-Kur'âni'l-Azîm, 5/210, 211.

125 İbn Kesîr, Tefsîru'l-Kur'âni'l-Azîm, 7/9, 10.

126 İbn Kesîr, Tefsîru'l-Kur'âni'l-Azîm, 7/19.

127 İbn Kesîr, Tefsîru'l-Kur'âni'l-Azîm, 7/32.

128 İbn Kesîr, Tefsîru'l-Kur'âni'l-Azîm, 7/37, 38.

129 İbn Kesîr, Tefsîru'l-Kur'âni'l-Azîm, 7/71, 72.
} 
kelimenin mezîd bâblarından if'âl bâbında Allah'ın kulları arasından bazılarını seçmesini, istif'âl bâbındaki formu ise bir insanın birini kendisine tahsis etmesini ifâde etmektedir. Dolayısıyla ilkinde Allah'ın, ikincisinde ise insanın birini tercih etmesi ve seçmesi durumu söz konusudur. Kelimenin isim kullanımlarında ise hem hakîkî hem de mecâzî kullanımlar bulunmaktadır. Ayrıca kelimenin isim formlarında genellikle azınlık bir grup diğerleri içerisinden istisna edilmektedir. Üstelik söz konusu âyetlerde kelime "ihlâs" haliyle geçmemektedir. Buna rağmen maddenin kök kullanımları içerisinde "ihlâs" formu daha yaygın bir terim anlam ifâde etmektedir. Bu da maddenin söz konusu formu üzerinde odaklanılmasına sebebiyet vermektedir.

\section{2. İhlâs Kavramının Tahlili}

İhlâs genel olarak herhangi bir işin saf ve samimi bir şekilde yapılması gibi manalarına gelmekle birlikte özel olarak dünya faydalarını düşünmeden bütün işleri, ibadet ve davranışları yalnız Allah için, Allah'a has kılarak icra etmeyi, zihni başka düşüncelerden temizleyip riya ve gösterişten uzak durmayı ihtiva etmektedir. ${ }^{130}$ İhlâsın hakikati Allah Teâlâ dışındaki her şeyden uzaklaşmaktır. ${ }^{131}$ Daha özel anlamıla Müslümanlar için ihlâs, Yahudiler'deki "Teşbih", Hristiyanlardaki “Teslis" iddialarından uzak durmayı ifâde etmektedir.132 Nitekim Kur'ân-1 Kerim'de bu "Hakikaten Allah üçün üçüncüsüdür diyenler kesin olarak kâfir olmuştur." "133 âyetinde görülmektedir. Kur'an' da ihlâs kavramının mahiyeti incelendiğinde ise âyetlerde geçen kelime türevlerine göre kavramı temelde öznesi ve nesnesi açısından olmak üzere iki kısımda ele almak mümkündür. Zira aynı fiilin fâiline göre taşıdığı anlam farklılaşabilmektedir.

\section{1. İhlâsın Kısımları}

Kur'ân âyetlerinde ifâde ettiği anlam cihetinden öznesine göre ihlâsı, öznesi Allah olan ve öznesi insan olan ihlâs olmak üzere iki kısımda değerlendirmek mümkündür.

\subsection{1. Öznesi Açısından İhlâs}

Özne Allah olduğunda fiil "Birini ihlâslı kılmak, ona ihlâs vasfını vermek", özne insan ise fiil "ihlâslı olmak" anlamına gelmektedir. Allah Teâlâ kullarına ihlâsı vehbî ve kesbî olarak lütfetmiştir. O halde öznesi Allah olan ihlâs kendi içerisinde peygamberlere verilen ihlâs ve diğer insanlara verilen ihlâs olmak üzere iki aşamada ele alınabilir.

Bu kısımda öncelikle Allah'ın peygamberlere verdiği ihlâs üzerinde durulmaktadır. Allah diğer insanlar arasında seçkin kıldığı peygamberlere vehbî olarak ihlâsı bahşetmiştir. Esasında peygamberlerin nübüvvetten öncesi de dâhil olmak üzere işledikleri hayırlı amelleriyle ihlâs vasfını kesbî olarak da elde ettikleri vâkidir. Ancak peygamberler diğer insanlardan vehbî ihlâsları ile temayüz etmektedirler. Nitekim konuyla ilgili olarak şu âyet zikredilebilir:

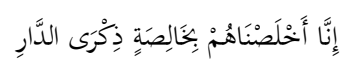

"Biz onları ahiret yurdunu düşünen, gönülden bağlı kullar kıldık."134

Âyette gönülden bağlı olan kullarla, bir önceki âyette zikredilen İbrahim, İshâk ve Yâkûb (a.s.) peygamberlerin ayrıcalıklı yönleri kastedilmektedir. Sürekli ahireti hatırlayan ve hiçbir düşünceyi

\footnotetext{
130 Ali b. Muhammed el-Hafî et-Tehânevî, Keşşâfu Istılâhâtı'l-Fünûn (Beyrut: Dâru'l-Kütübü'l-İlmiye, 1998), 4/44; es-Seyyîd eşŞerîf el-Cürcânî, Ali b. Muhammed el-Hüseynî el-Hanefî, et-Tarifât, thk. Muhammed Abdurrahman Maraşlî ( Beyrut: Dâru'nNefâis, 2003), 70; Âsım Efendî, "hls", 2/374.

131 Râgib el-Isfahânî, Müfredâtu Elfâzi'l-Kur'ân (Beyrut: Daru'l-Kalem, 2002), 29; Fîrûzâbâdî, Muhammed b. Yakub, Besâir-u Zevi't-Temyiz fî Letaifu'l-Kitâbi'l-Azîz (Beyrut: el-Mektebetü'l-İlmiyye, ts.), 2/173.

132 Râgib el-Isfahanî, Müfredât, 292; el-Fîrûzâbâdî, Besâir-u Zevi't-Temyiz, 2/173.

133 el-Mâide 5/73.

134 es-Sâd 38/46.
} 
ahiretin önüne geçirmeme hasletine sahip olan kulların, kendilerine bahşedilen bu hasletleri hasebiyle seçkin kılındıkları ifâde edilmektedir. ${ }^{135}$ Başka bir âyette de Allah Teâlâ Hz. İbrahim'i andıktan sonra Hz. Mûsâ'yı şu şekilde ihlâslı bir kul olarak nitelendirmektedir:

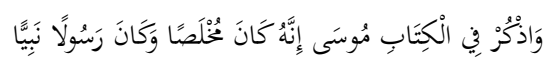

"Kitab'ta Mûsâ'yı da an. O seçkin kılınmış bir kul, tarafımızdan gönderilmiş bir peygamberdi."136

Allah sadece bu âyette değil başka bir âyette de Hz. Musa'nın insanlar arasından seçildiğini haber vermektedir. ${ }^{137} \mathrm{Bu}$ konudaki bir diğer âyette ise Yûsuf (a.s.) ile azizin hanımı arasında geçen

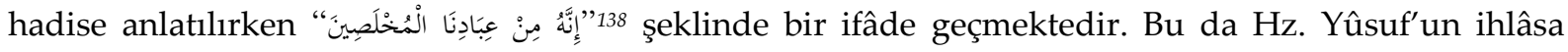
erdirilmiş kullardan olduğu anlamına gelmektedir. Hz. Yûsuf, haramlardan uzak durma hususunda mükelleflerden alınan kesin delil vesilesiyle büyük bir bela karşısında gösterdiği büyük sabırdan dolayı övülmüştür. ${ }^{139} \mathrm{O}$ halde Allah Teâlâ nebî kullarını diğer insanlardan üstün kılmış ve onları ihlâslı kulları içinde ayrı bir derecede tutmuştur.

Allah'ın insanlara verdiği ihlâs hususundaki âyetler incelendiğinde Allah Teâlâ'nın kullarını, kendi rızası doğrultusundaki amelleri neticesinde diğer insanlardan seçkin kıldığı görülmektedir. Dolayısıyla Allah kullarına ihlâsı bahşetmekte, kulları da onun bu lütfuyla ihlâsa nâil olmaktadır.

Öznesi insan olan ihlâsla ilgili âyetleri ise kendi içerisinde mümin, kâfir ve münâfıkların ihlâsı olarak üç aşamada değerlendirmek mümkündür. Nitekim Zümer Sûresi'nin şu âyetinde ihlâsın öznesi dini Allah'a has kılan insandır:

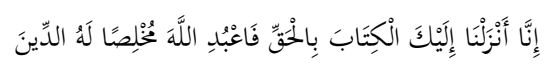

"Şüphesiz ki bu Kitab'ı sana hak olarak indirdik. O halde sen de dini Allah'a has kularak kulluk et."140

Burada kelime ile kastedilenler şirk, riyadan ve her türlü şüpheden uzak olarak, tevhid üzere dini Allah'a has kılandır. Zira Allah kullarına nimetlerini herhangi bir menfaat beklemeksizin lütfettiğinden buna müstahaktır. ${ }^{141}$ Allah Teâlâ bir diğer âyette nebisi şahsında bütün inananlara sadece kendisine ibadet edip kendisi dışındakilere ubûdiyeti terk etmeyi emretmektedir:

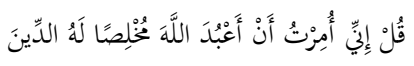

"De ki: 'Ben, dini yalnzzca kendisine has kllarak Allah'a ibadet etmekle emrolundum."142

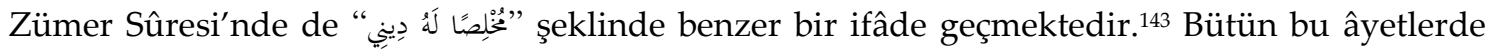
ihlâs kelimesi ile ilgili olarak "insan" özne konumundadır. Ancak insanlardan hangilerinin kastedildiği hususu üzerinde daha detaylı olarak durulabilir. Bu bağlamda zikri geçen âyetler

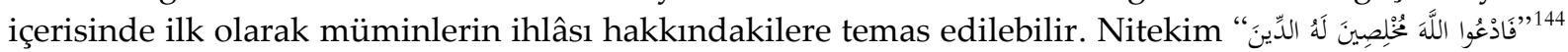

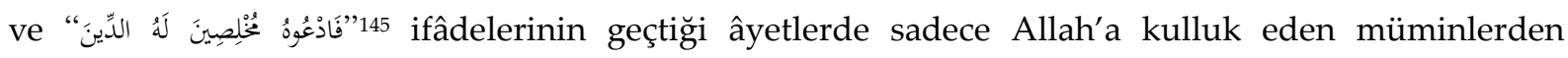
bahsedilmektedir.

\footnotetext{
135 Zemahşerî, el-Keşşâf, 5/274, 275.

136 el-Meryem 19/51.

137 el-A'râf 7/144.

138 el-Yûsuf 12/24.

139 Zemahşerî, el-Keşşâf, 3/267-270.

140 ez-Zümer 39/2.

141 Zemahşerî, el-Keşşâf, 5/286, 287.

142 ez-Zümer 39/11.

143 ez-Zümer 39/14.

144 el-Mü'min 40/14

145 el-Mü' min 40/65.
} 
Kâfirlerin ihlâsı hususundaki âyetler ise birkaç farklı şekilde tezahür etmektedir. Söz gelimi şu âyet zikredilebilir:

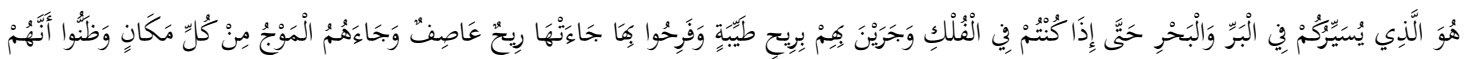

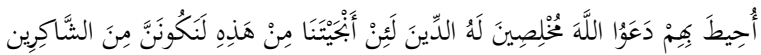

“Sizi karada ve denizde yürüten O'dur (Allah'tır). Öyle ki siz gemilerde bulunduğunuz, o gemiler de içindekileri hoş bir esinti ile götürdükleri ve (yolcular) bu yüzden neşelendikleri zaman, o gemiye şiddetli bir firtına gelip çatar ve dalgalar her taraftan onları sarar, onlar çepeçevre kuşatıldıklarını anlarlar da dini yalnız Allah'a has kılarak: 'And olsun eğer bizi bundan kurtarırsan mutlaka şükredenlerden olacă̆ı.' diye Allah'a yalvarirlar." 146

Âyette inkâr edenlerin başlarına gelen bir tehlike anında ibadeti sadece Allah'a has kılmaya yönelik ifâdeleri söz konusudur. Ancak müminlerinkinden farklı olarak kâfirler, Allah'a ibadet etmek için karşılaştıkları tehlikeden kurtulmayı şart koymaktadırlar. Hâlbuki hakikî ihlâs herhangi bir menfaat olmaksızın sadece Allah rızası için samimiyeti gerektirmektedir. Ancak onlar dalgalar etraflarını sardığında Allah'la beraber bir başkasına dua edemediklerinden şirk koşmaksızın yalvarmış olmaktadırlar. ${ }^{147}$ Aynı şekilde gemiye bindiklerinde yürekten Allah'a yalvarıp karaya varınca ona ortak koşanlarla ilgili olarak da "Dini Allah'a has kılarak O'na yalvarırlar"148 meâlindeki “ " دَّ

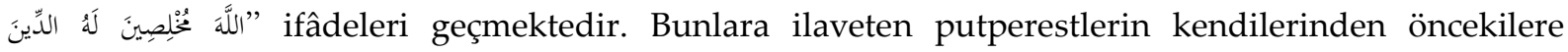
verilenlerden bir kitap olması halinde Allah'ın ihlâslı kullarından olacaklarını ileri sürdüklerine dair

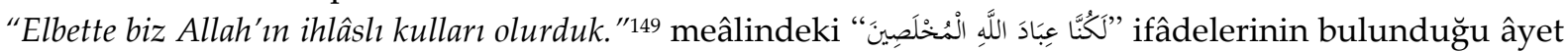
de yine ihlâsın öznesinin kâfirler olması bağlamında değerlendirilebilir. Hâlbuki Allah Teâlâ "Onlara

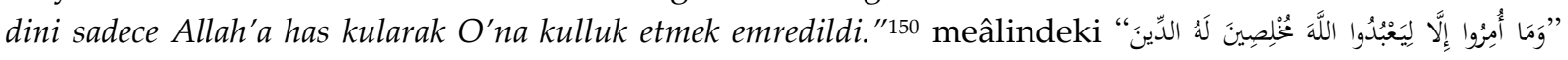
âyetiyle kâfirlere kendisine kulluk etmeyi, dolayısıyla da onların kendi hallerine bırakılmadıklarını bildirmektedir.

Münâfıkların ihlâsı hakkında onların tövbe etmeleri durumu ile ilgili olarak zikredilen âyet üzerinde durulabilir. Allah müminleri bırakıp kâfirleri dost edinen münâfıkları uyarmakta ve onların cehennem ateşinin en alt tabakasında olacağını ifâde eden âyetin ${ }^{151}$ ardından “ " buyurmaktadır. Dolayısıyla münâfıklardan samimi olarak tövbe edip Allah'a yönelenlere dair bir istisna söz konusudur. Nihâyetinde âyetlerde öznenin mümin, kâfir ve münâfık olmasına göre durumları farklı bağlamlarda ortaya çıkmaktadır.

\subsubsection{Nesnesi Açısından İhlâs}

Âyetlerdeki geçiş şekillerine göre nesnesi açısından ihlâsı ise iman ve amel olmak üzere iki kısımda değerlendirmek mümkündür. Bunlardan ilki iman alanındaki ihlâstır. Bu konuda zikredeceğimiz âyet, amelle birlikte dile getirilse de esasında âyette imana ihlâs açısından vurgu yapılmaktadır. Söz konusu kısımda Allah nebisine müşriklerle mücadele etme hususunda yol

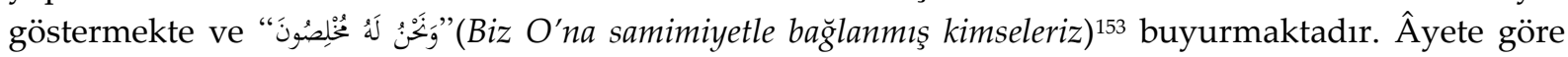
Allah'ın birliği ve ona ihlâsla boyun eğmek hususunda müşriklerin müminlerle münakaşa etmesi

\footnotetext{
146 Yûnus 10/22.

147 Zemahşerî, el-Keşşâf, 3/126.

148 el-Ankebût 29/65; el-Lokman 31/32.

149 es-Sâffât 37/169.

150 el-Beyyine 98/5.

151 en-Nisâ 4/145.

152 en-Nisâ 4/146.

153 el-Bakara 2/139.
} 
yadırganmaktadır. Oysa Allah'a samimi olarak ubûdiyet açsından müminlerin müşriklerle mukayese edilecek bir tarafı bulunmamaktadır.

Amel alanındaki ihlâs hususunda ise âyetler, sâlih ve fâsid olmak üzere iki açıdan ele alınabilir. Bu minvalde sâlih amel kapsamında âyetlerde fitrata ittibâ, Allah ile Hz. Peygamber'e (s.a.v.) itaat ve şeytana muhalefet gibi dört husus dikkat çekmektedir. Bunlardan ilki olan fitrata itaat, ihlâsla irtibatlı

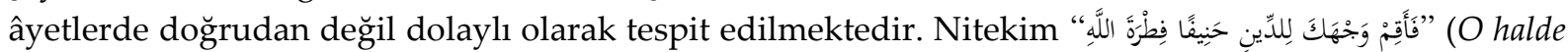
yüzünü bir hanif olarak dine, Allah'ın fitratına çevir $)^{154}$ ifâdelerinin geçtiği Rûm Sûresi'nde gerçek din olan tevhîd dinine yönelmek emredilmektedir. İhlâsla ilgili zikredilen âyetlerde din ile ilgili aynı vurgu söz konusudur. Dolayısıyla bu dinin saf ve samimi hali fıtratta insana bahşedilmiştir. Bu yüzden fıtrat üzere dine yönelme ile ihlâs arasındaki ilişki ortaya çıkmaktadır. İkinci olarak sâlih amel bağlamında Allah'a itaat hususunda şu âyet zikredilebilir:

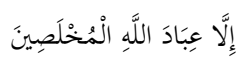

"Allah'ın ihlâsa erdirilmiş kulları müstesna."155

Allah Teâlâ herkesin yaptığıyla cezalandırılacağını söyledikten sonra ihlâslı olan insanları bu şekilde istisna etmiştir. Buradaki istisnanın çeşidinin müstesna ve müstesna minhin ayrı türden kabul edildiği ileri sürülmüştür. ${ }^{156}$ Devamındaki âyetlerde bu kullara lütfedilecek nimetler zikredilmektedir.

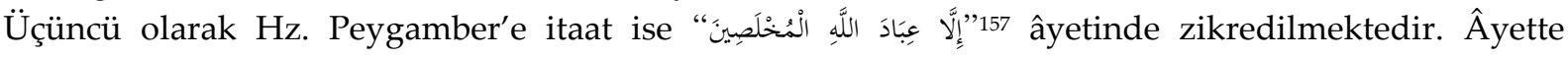
müşriklerin Allah Teâlâ hakkında ileri sürdüklerinden ihlâslı kulların beri olduğu ifâde edilmektedir. Nitekim onlar meleklerle ilgili asılsız ithamlarda bulunmuşlardır. Bu bakımdan âyette Allah'ın ihlâsa erdirilmiş kulları daha açık bir ifâde ile peygamber ve resûle indirilen gerçeğe tabi olanları, bütün insanlardan istisna edilmiştir.

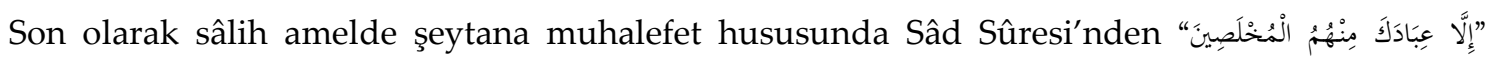
âyetini158 zikretmek mümkündür. Bu âyet Allah'ın meleklere Hz. Âdem'e secde etmelerini emretmesiyle alakalıdır. Allah Kur'ân'da birkaç farklı sûrede bu meseleyi zikretmiştir. Nitekim Allah Teâlâ bu hususu Bakara Sûresi'nde,159 A'râf Sûresi'nin başında, ${ }^{160}$ Tâhâ, İsrâ, Kehf ve Sâd Sûreleri'nde ${ }^{161}$ haber vermektedir. Melekler secde etmişler ancak İblis secde etmemiş, kendisini Hz. Âdem'den üstün tutmuş ve kovulmuştur. ${ }^{162}$ İblis Allah'tan kendisine âdemoğullarını azdırmak üzere mühlet vermesini istemiş ancak sonraki âyetlerde bütün kullar arasından ihlâslı olanlarını istisna etmiş başka bir ifâde ile onları azdıramayacağını ikrar etmiştir. ${ }^{163}$ Böylelikle ihlâsın sâlih amelle ilgili kısmı ana hatlarıyla ele alınmış olmaktadır. Buna mukabil ihlâsın fâsid amelle ilgili kısmına dair âyetleri de kendi arasında nefse ittibâ, Allah'a ve Hz. Peygamber'e itaatsizlik ve şeytana itaat olarak dört şekilde incelemek mümkündür. ${ }^{164}$ Ancak bu husustaki âyetlerde zikredilen hasletlerin kınandığ 1 ve bu eylemlerde bulunmayanların diğerleri nezdinde daha itibarlı olduğu görülmektedir. Bu minvalde nefse ittibâ hususunda Allah'ın Kur'ân'da kullarına ikazı söz konusudur. ${ }^{165}$ Zira insan kendisine nefsinin emrettiği kötülüklerin güzel görünmesinden ötürü nefsine uymakta ve işlediği

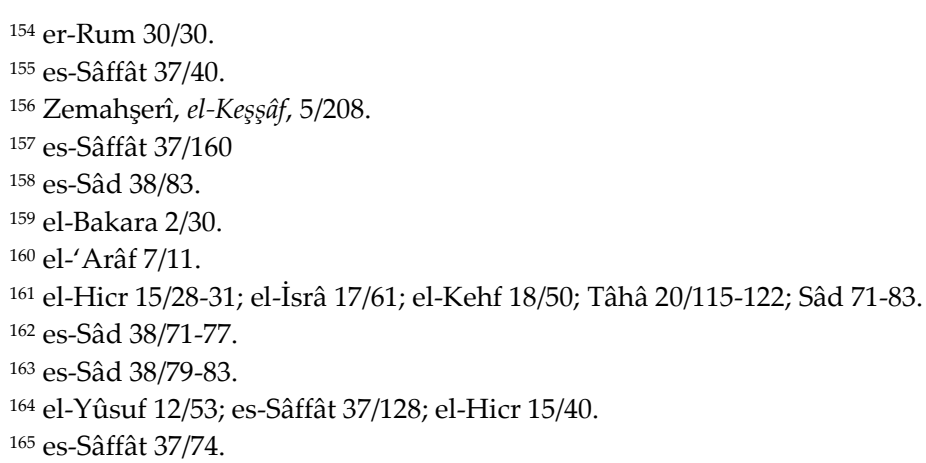


güzel ameller de boşa çıkmaktadır. Bu nedenle Allah şu âyette nefsin kötülükleri emrettiğini kullarının nazarına sunmaktadır:

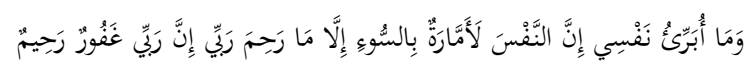

"Ben nefsimi temize çıkarmam; çünkü nefis, Rabbimin merhameti olmadıkça, kötülüğü emreder. Doğrusu Rabbim bağışlayandır, merhamet edendir." 166

Allah'a itaatsizlik hususunda ise şirkin asla affedilmeyeceği ancak ihlâsla nefislerini temizleyen kulların ayrı tutulacağı haber verilmektedir. ${ }^{167}$ Öte yandan Hz. Peygamber'e itaatsizlik ile

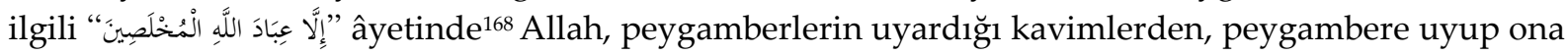
muhalefet etmeyenleri istisna etmektedir. Esasında Allah geçmiş ümmetler hakkında, kendisini inkâr ederek başkasına kulluk edenleri azabından koruyacak uyarıcı peygamberler gönderdiğini ancak kavimlerinin onların yalanlamaları üzerine helâk olduklarını haber vermekte ve uyarılanlar içerisinde peygambere itaat edenleri diğerlerinden ayırmaktadır. Son olarak şeytana itaatsizlik konusunda ise daha önce ifâde edildiği üzere İblis'in kulları saptırırken ihlâslı olanları istisna etmesinin ifâde edildiği âyetlerden biri olan “" "169 zikredilebilir. Zira İblis onları tuzağa düşüremeyeceğini ve onların bunu kabul etmeyeceğini bilmektedir. ${ }^{170}$ Dolayısıyla şeytana itaat amelin fâsid olmasına neden olmaktadır. Böylelikle bu araştırmada sâlih ve fâsid ameller hakkındaki âyetler, birbirinin zıddı olan başlıklar açısında tasnif edilmiştir.

\section{3. İhlâsın İlişkileri}

İhlâsın ilişkili olduğu kavramlar da ihlâsın mahiyetinin anlaşılması açısından üzerinde durulmaya değerdir. Zira ihlâs, amel ve niyet arasında üçlü bir ilişki söz konusudur. İhlâs-niyet ilişkisi sıdk, rıza ve riya kavramları çerçevesinde değerlendirilebilir. Nitekim sıdık ve rıza samimi niyete ulaşmaya yardımcı unsurlardır. Sadâkat, peygamberlerin birinci vasfı, ihlâs ise Cenâb-1 Hakk'ın peygamberlerine doğrudan mazhar kaldığı ilahi bir lütfudur. ${ }^{171}$ Sadâkata bağlı ameller, kulun Allah'ın inâyeti ve gözetiminde olduğunu bilmesiyle irtibatlıdır. İhlâs, yaptığı her işi Allah'ın istediği şekilde ve rızası doğrultusunda yapmak; rıza ise O'nun bütün emir ve tecellilerine razı olmaktır. Öte yandan riya genellikle ihlâsın zıddı olarak kullanılmaktadır. Riyanın sadece dünyayı istemek ve amelle dünya ve ahiret menfaatini birlikte ummak gibi iki yönü bulunmaktadır. Ayrıca ihlâsın zıt anlamlısı olarak iştirak da zikredilmektedir. İhlâs'ın kemali ise doğruluktur. ${ }^{172}$

Râzî, tefsirinde niyet ve ihlâs arasındaki ilişkiyi dile getirirken kalbi Allah'ın rızasından başka her şeyden arındırmak gerektiğine dikkat çekmekte ve Hz. Peygamber'in "Ameller niyetlere göre değerlendirilir"173 hadisini hatırlatmaktadır. ${ }^{174}$ Dolayısıyla amellerdeki samimi niyet, cehennem korkusu veya cennet ümidi gibi herhangi bir beklenti olmaksızın sadece Allah rızası için eylemlerde bulunmayı ifâde etmektedir.

İhlâs-amel ve amel-niyet ilişkileri de ayrıca dikkate alınmalıdır. İhlâs-amel ilişkisinde ise amelin ihlâsla mı yoksa gösteriş olarak mı yapıldığı sorgulanmaktadır. Bu bakımdan ameller itaat, günah ve mubah gibi farklı şekillerde tezahür etmektedir. İslam insanı fıtratına uygun bir şekilde

\footnotetext{
${ }^{166}$ el-Yûsuf 12/53.

167 es-Sâffât 37/128.

168 es-Sâffât 37/74.

169 el-Hicr 15/40.

170 Zemahşerî, el-Keşşâf, 3/407.

171 Bk. Yûsuf 12/24, Meryem 19/51, es-Sâffât 37/128.

172 et-Tehânevî, Keşşâfu Istılâhâtı'l-Fünûn, 4/44.

173 Buhârî, el-Câmiu's-sahîh, "Bedü'1-Vahy", 1 (no. 1).

174 Ebû Abdillâh Fahrüddîn Mahammed b. Ömer b. Huseyn er-Râzî, et-Tefsîru'l-Kebîr: Mefâtihu'l-Gayb (Beyrut: Dâru'l-Fikr, $1401 / 1981), 11 / 42$.
} 
yönlendirirken onun kemâle ermesinin yollarını açar. Bu bağlamda yaptığı amele Allah'tan başka bir şahit aramamak amelleri sadece onun rızası için işlemeyi sağlamaktadır.

Amel-niyet ilişkisi hususunda insanlar amelleri açısından amel ve niyetlerinde ihlâslı olanlar, amellerinde ihlâslı olup niyetlerinde ihlâs bulunmayanlar ve ihlâstan nasibi olmayanlar şeklinde üç kısımda değerlendirilebilir. Bunlardan sadece amel ve niyette Allah'ın rızasını gözetenler hakikî anlamda ihlâsa sahip kimselerdir.

İhlâsın mahiyeti Kur'ân âyetleri üzerinden değerlendirildiğinde İslam âlimlerinin terime zaman içerisinde yükledikleri anlamların âyetlere dayandığı ifâde edilebilir. Bu araştırmada ihlâsla ilgili âyetler sözlükler ve dil bilimin imkânları çerçevesinde detaylı bir tasnife tutulmuştur. Böylelikle kavramın öne çıan belirli yönlerinin yanı sıra ihmâl edilen anlamlarına da dikkat çekilmiştir.

\section{Sonuç}

Kur'ân muhtevası hakkında yapılan çalışmalardan biri olan kavram tahlilleri tefsir araştırmalarına yön vermektedir. Bu minvalde bu araştırmada "ihlâs" kavramı tahlil edilmiştir. Her ne kadar söz konusu kavramla ilgili bazı çalışmalar yapılmışsa da mevcut literatür içerisindeki eserlerin ya tasavvuf ya da fıkıh gibi alanlardaki verilere yoğunlaştığı, buna mukabil kavramın sözlüklerdeki ve Kur'ân âyetlerindeki durumunun detaylı tasnifi hususunda sinırlı kaldıkları tespit edilmiştir. Nitekim yapılan çalışmalarda kavramın kelime kökünü teferruatlı bir şekilde ele alınamamaktadır. Ayrıca çalışmalar konu hakkındaki âyetlerle ilgili sayısal verilerle sınırlı kalmaktadır. Bu nedenle bu araştırmada öncelikle kelime kökü sözlüklerde detaylı bir şekilde incelenmiş, ardından Kur'ân âyetleri açısından genel bir tablo oluşturulmuştur. Böylelikle kelimenin kökünün daha nesnel bir şekilde ortaya çıkarılması amaçlanmıştır. Bu bağlamda araştırma esnasında kategorilere ayırma yöntemine başvurulmuştur.

Araştırmanın ilk bölümü olan sözlüklerle ilgili kısımda sadece "ihlâs" kelimesi değil, aynı zamanda bu kelimenin köken itibariyle irtibatlı olduğu bütün türevleri incelenmiştir. Bu minvalde ilk dönem sözlüklerinden başlamak suretiyle kadîm sözlüklerdeki veriler teker teker incelenmiştir. Kelimenin daha sonradan kazandığı anlamlar ve mevcut kavramlarının daha iyi anlaşılabilmesi açısından kelime kökleri, Arapça dil yapısı gereği fiil ve isim olmak üzere tasnif edilmiştir. Diğer taraftan kelimenin Kur'ân' da "ihlâs" şeklinde geçmemesine rağmen bu manayı ifâde etmekle birlikte bu kökten türeyen kelimelerin geçtiği âyetlerde kelime, Arap dilindeki kısımla irtibatlı olarak fiil ve isim türevlerine ayrılmıştır. Dolayısıyla ilk kısım gerek sözlükler gerekse Kur'ân âyetleri kapsamında bir tür sarf tahlili şeklinde sunulmuştur. Buna göre kelimenin sülâsi mücerred ve mezîd fiilleri ile isim formlarında kök anlamıyla irtibatlı hakikî ve mecâzî kullanımların olduğu tespit edilmiştir. Kelimenin her iki kullanımı da bağlama göre şekillenmiştir.

Araştırmanın ikinci bölümünde ise ihlâsın mahiyetini ortaya koymak üzere zikredilen âyetler, yeni bir tasnife tabi tutulmuştur. Bu bağlamda kelimelerin ilk bölümdeki sarf açısından ifâde ettiği manalar da göz önüne alınarak, nahiv bağlamında başka bir ifâde ile cümlenin öğeleri açısından özne ve nesneye dair bir tasnif hazırlanmıştır. Özne ile ilgili olan kısımda âyetlerde ihlâs, öznesi Allah ve insan olan ihlâs olmak üzere iki aşamada değerlendirilmiştir. Bu kısımda Allah söz konusu olduğunda ihlâsı bahşetmek, insanla ilgili olarak ise ihlâslı olmak gibi manalara dikkat çekilmiştir. Bu minvalde Allah'ın ihlâsı vehbî ve kesbî olarak iki şekilde kullarına lütfettiğine işaret edilmiştir.

Diğer taraftan ihlâsın nesnesi açısından tahlilinde ise öncelikle iman ve amel ayrımı yapılmış ardından amel, kendi içerisinde sâlih ve fâsid olarak iki kısımda değerlendirilmiştir. Söz konusu kısımların alt başlıkları birbirine zıt olarak hazırlanmıştır. Nitekim sâlih amel kısmında âyetlerin fıtrata ittibâ, Allah Teâlâ ve Hz. Peygambere (s.a.v.) itaat ve şeytana muhalefet gibi başlıklarda tasnif edilmesine karşın; fâsid amel kısmında ise nefse ittibâ, Allah Teâlâ ve Hz. Peygamber'e (s.a.v.) 
itaatsizlik ve şeytana itaat başlıkları tespit edilmiştir. Dolayısıyla ihlâsı anlamak için bu zıtlıklar göz önüne alınmıştır. Böylelikle ihlâsın kısımları tespit edilmeye çalışılmıştır.

İhlâsın kısımlarından sonra ikinci aşamada ihlâsın ilişkili olduğu kavramlara da değinilmiştir. Bu bağlamda niyet kısmında sıdk, rıza ve riya gibi başlıklar öne çıkarken amel ve niyet ile ihlâs arasındaki ilişki de ihlâsın mahiyetini değerlendirmeye imkân sağlamıştır.

$\mathrm{Bu}$ araştırmaya göre ihlâs; umûmî anlamda yapılan her işte samimiyeti, hususî olarak ise ibadeti sadece Allah'a mahsus kılmayı ifâde etmektedir. Diğer taraftan 1stılahî olarak yerleşen ikinci anlamıyla ihlâs, cennet mükâfatı veya cehennem korkusu gibi herhangi bir beklenti içerisinde olmadan sadece Allah rızası için davranış sergilemek anlamına gelmektedir. Ancak bu mana öznenin insan olduğu durumda geçerlidir. Buna ilaveten kelimenin sözlüklerde ifâde ettiği anlam genişliği âyetlere de yansımaktadır. O halde ihlâsın mahiyetinin ortaya koyulabilmesi için kavramın sadece özneye değil aynı zamanda nesneye göre de değerlendirilmesi beklenir. Dolayısıyla kavram tahlili çalışmalarını bazı alanlarla ilgili verilerle sınırlamak yerine, kelimelerin Arap dilindeki kök yapısı ve âyetlerdeki ifâde tarzları üzerinden yapılması nitel verilerin sunulmasına katkı sağlayabilmektedir. Ancak bu durum, bir kavramın Kur'ân'daki anlam alanının anlaşılması hususunda salt sözlükler ve dilbilgisi kâidelerinin yeterli kaldığını göstermez. Zira âyetler söz konusu olduğunda bağlamın anlaşılması açısından rivâyetlerin ve belâgatın imkânlarına da müracaat etmek gerekecektir. Ne var ki rivâyetler ve belâgatın anlam için destekleyici unsurlar olarak bulunması nedeniyle bunların sınırlı bir şekilde kullanılması beklenmektedir. Kavram çalışması yapılırken, ihlâs kavramının gerek hakikî gerekse mecâzî anlamında bulunduğu gibi, kavrama sonradan dâhil edilen anlamların ayrıştırılması ve kök anlamının Kur'ân'daki kullanım şekillerine göre irdelenmesi manayı daha nesnel bir şekilde sunabilmeyi sağlayacaktır.

\section{Kaynakça}

Acar, Gülen. Kur'ân-ı Kerîm'de İhlâs. Ankara: Ankara Üniversitesi Sosyal Bilimler Enstitüsü, Yüksek Lisans Tezi, 1995.

Ahmed b. Fâris, Ebû́'l-Huseyn ez-Zekeriyya. Mücmelü'l-lüga. 4 Cilt. Beyrut Müessesetü'r-Risâle, 1984.

Akçay, Yusuf. "Kur'ân'ın İlk Tercümeleri ve Mustafa b. Muhammed'in İhlâs Sûresi Tefsiri". Dil ve Edebiyat Araştırmaları Dergisi 5 (2012), 125-140.

Âsım Efendî, Ebû'l-Kemâl Ahmed. el-Ûkyânûsu'l-Besît fî tercemeti'l-Kâmûsi'l-Muhît. 3 Cilt. İstanbul ts.

Bilmen, Ömer Nasûhî. Kur'ân-ı Kerîm Meâli Âlisi ve Tefsiri. sad. Muhsin Demirci, Sadrettin Gümüş. 8 Cilt. İstanbul: İpek Yay., ts.

Buhârî, Ebû Abdillâh Muhammed b. İsmâil. el-Câmiu's-sahîh. nşr. Ebû Suheyb el-Kermî. Riyad: Beytü'l-Efkâri'd-Devliyye li'n-Neşr, 1419/1998.

Cevherî, Ebû Nasr İsmâîl b. Hammâd. es-Sihâh Tâcü'l-Lüga ve Sihâhü'l-'Arabiyye. thk. Ahmed Abdülğafûr 'Attâr. 7 Cilt. Kâhire: Dâru'1-i̇lm li'1-Melâyîn, 1399/1979.

Ceyhan, Semih - Gümüştekin, İslim. "İşârî İhlâs Tefsiri Risâleleri". Türkiye Araştırmaları Literatür Dergisi 15/30 (2017), 317-371.

Cürcânî, es-Seyyîd eş-Şerîf Ali b. Muhammed el-Hüseynî el-Hanefî. et-Tarifât. thk. Muhammed Abdurrahman Maraşlî., Beyrut: Dâru'n-Nefâis, 2003.

Ekin, Yunus. "İhlâs Kavramının Semantik Analizi”. Tasavvuf: İlmî ve Akademik Araştırma Dergisi 3/9 (2002), 147-160.

Eroğlu, Ali. “Ekmelüddîn Bâbertî'nin İhlâs Sûresi'nin Tefsirine Dair Risâlesi Üzerine Bir Değerlendirme". Ekmelüddin Bâbertî'yi Keşif Yolunda I. Ekmelüddîn Bâbertî Sempozyumu 28-30 Mayıs 2010. ed. Selçuk Coşkun. Erzurum: Bayburt Üniversitesi Yayınları 2014, 535-542.

Fîrûzâbâdî, Muhammed b. Yakub. Besâir-u Zevi't-Temyiz fì Letaifu'l-Kitâbi'l-Azîz. 6 cilt. Beyrut: elMektebetü'l-illmiyye, ts.

Halîl b. Ahmed. Kitâbu'l-'Ayn. Beyrut: Mektebetü'l-Lübnan, 2004. 
Izutsu, Toshihiko. Kur'ân'da Dînî ve Ahlâkî Kavramlar. çev. Selahattin Ayaz. İstanbul: Pınar Yayınları, 2010.

İbn Düreyd, Ebû Bekr Muhammed b. Hasen. Cemheratü'l-lüga. 3 Cilt. Beyrut: Daru'l-İlm li'l-Melâyîn, 1987.

İbn Hacer el-Askalânî. Fethu'l-Bârî bi Şerhi Sahîhi'l-Buhârî. nşr. Ebû Kuteybe Nazar Muhammed elFaryâbî. 17 Cilt. Riyad: Dâru Taybe, ts.

İbn Kesîr, Ebü'l-Fidâ. Tefsîru'l-Kur'âni'l-Azîm. 9 Cilt. Beyrut: Dâru'l-Kütübi'l-ilmiyye, 1998.

İbn Manzûr, Muhammed b. Mükerrem. Lisânü'l-'Arab. 15 Cilt. Beyrût: Dâru Sâdır, ts.

İbn Receb, Ebü'l-Ferec Zeynüddîn Abdurrahman b. Ahmed. Kelimetü'l-ihlâs ve Tahkiku Ma'nâhâ. Beyrut: elMektebetü'l-İslâmî, 4. Basım, 1397/1977.

Karagöz, İsmail. "Kur'ân'da İhlâs Kavramı ve Muhlis İnsanın Vasıfları". Diyanet İlmi Dergi 33/ 4 (1997), 69-84.

Muallim Nâci. Hulâsatü'l-íhlâs. Konstantiniye: Matbaatü Ebu'd-Diyâ, 1304/1886.

Muhammed Fuâd Abdülbâkî. el-Mu'cemu'l-Müfehres li Elfâzi'l-Kur'âni'l-Kerîm. 2 Cilt. Mısır: Dâru'lKütüb, 1945.

Özdemir, Ahmet. Kur'ân'da İhlâs". Gazi Osman Paşa Üniversitesi İlahiyat Fakültesi Dergisi 3/2 (2015), 153-166.

Öztürk, Ali. “Muallim Nâci (1849-1893)'nin “Hülâsatü'1-İhlâs” İsimli İhlâs Sûresi Tefsiri”. İslâmî İlimler Dergisi 7/2 (2012), 109-139.

Râgib el-Isfahânî, Müfredâtu Elfâzi'l-Kur'ân. Beyrut: Daru'l-Kalem, 2002.

Râzî, Ebû Abdillâh Fahrüddîn Mahammed b. Ömer b. Huseyn. et-Tefsîru'l-Kebîr: Mefâtihu'l-Gayb. 32 Cilt. Beyrut: Dâru'l-Fikr, 1401/1981.

Şevkânî, Ebû Abdullah Muhammed b. Ali. ed-Dürrü'n-Nadîd fi İhlâsi Kelimeti't-Tevhîd. Misır: Matbaatü'l-Menâr, 1340/1921.

Taberânî, Ebü'l-Kâsım Süleymân b. Ahmed b. Eyyûb. el-Mu'cemü'l-Kebîr. nşr. Hamdi Abdülmecîd esSelefî. 25. Cilt. Kahire: Mektebetü İbn Teymiyye, 1404/1984.

Taberî, Muhammed b. Cerîr. Câmiu'l-Beyân 'an Te'vîli Âyi'l-Kur'ân. thk. Abdullah b. Abdulmuhsin etTürkî. 26 Cilt. Kahire: Hicr, 1422/2001.

Tehânevî, Ali b. Muhammed el-Hafî. Keşsâfu Istılâhâtı'l-Fünûn. 4 Cilt. Beyrut: Dâru'l-Kütübü'l-ìlmiye, 1998.

Zebîdî, es-Seyyid Muhammed Murtazâ. Tâcu'l-'Arûs. 10 Cilt. Beyrût: Dâru'ṣ-Ṣâdır, 1306/1888.

Zemahşerî, Ebû'l Kâsım Cârullah Mahmûd b. Ömer. el-Keş̧âf 'an Hakâiki't-Tenzîl ve 'Uyûni Ekâvîl fî Vücûhi't-Te'vîl. thk. Adil Ahmed Ebû'l- Mevcûd - Ali Muhammed Muavvid. 6 Cilt. Riyâd: Riyâd: Mektebetü'l-Ubeykân, 1418/1998.

Zemahşerî, Ebû'l-Kâsım Cârullah Mahmûd b. Ömer. Esâsü'l-Belâga. 2 Cilt. Misır: Dâru'l-Kütüb, 2. Basım, 1972. 